Prepared for the U.S. Department of Energy

under Contract DE-AC05-76RL01830

\title{
Discrete Sampling Test Plan for the 200-BP-5 Operable Unit
}

\author{
MD Sweeney
}

February 2010

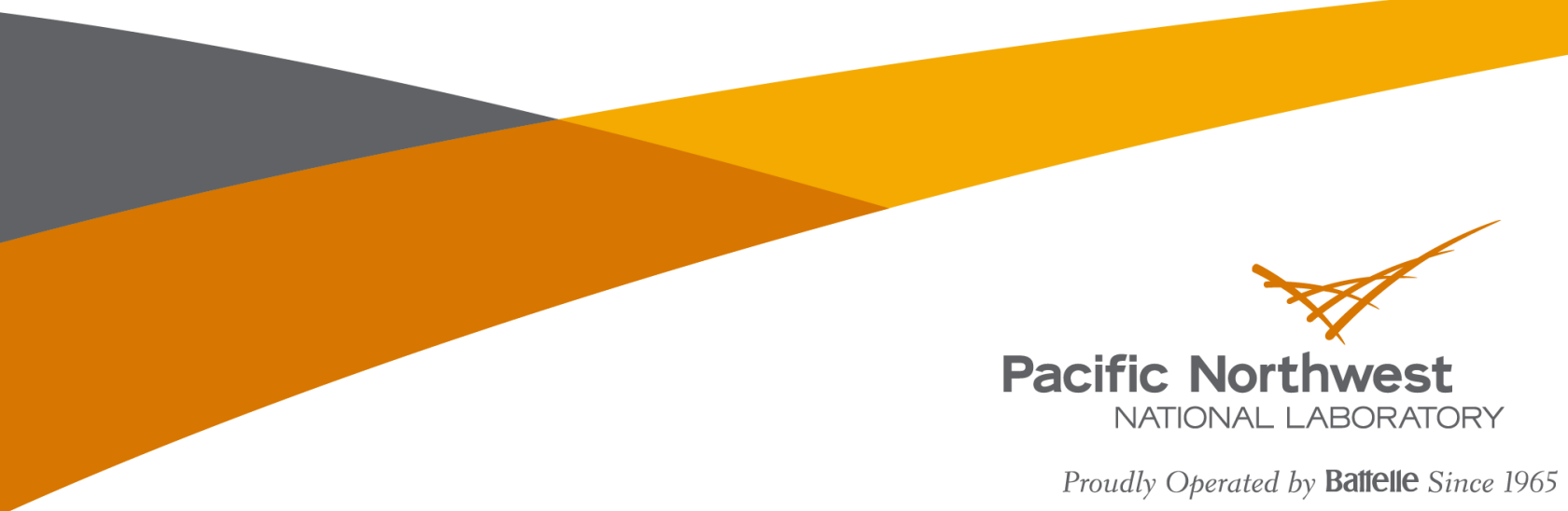




\section{Discrete Sampling Test Plan for the 200-BP-5 Operable Unit}

MD Sweeney

February 2010

Prepared for

CH2M HILL Plateau Remediation Company

and the U.S. Department of Energy

under Contract DE-AC05-76RL01830

Pacific Northwest National Laboratory

Richland, Washington 99352 



\begin{abstract}
The Discrete Groundwater Sampling Project is conducted by the Pacific Northwest National Laboratory (PNNL) on behalf of CH2M HILL Plateau Remediation Company. The project is focused on delivering groundwater samples from selected horizons within select groundwater wells residing in the 200-BP-5 Operable Unit (200-BP-5 OU) on the Hanford Site. This document provides the scope, schedule, methodology, and other details of the PNNL discrete sampling effort.
\end{abstract}





\section{Contents}

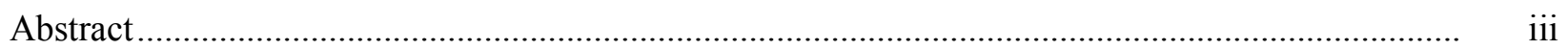

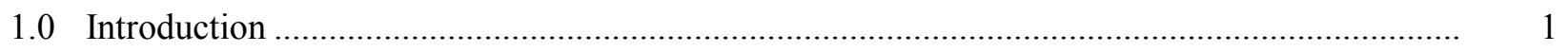

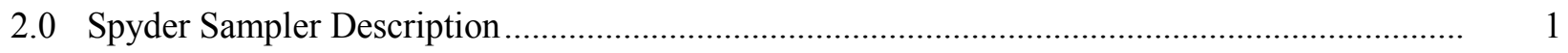

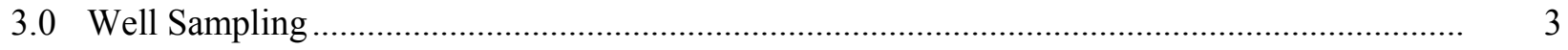

3.1 Well and Constitutent List.................................................................................. 3

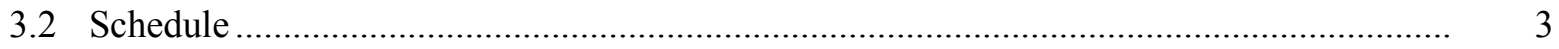

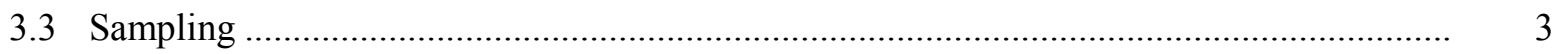

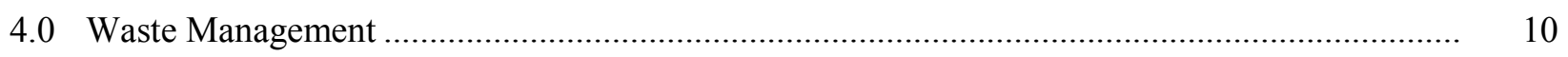

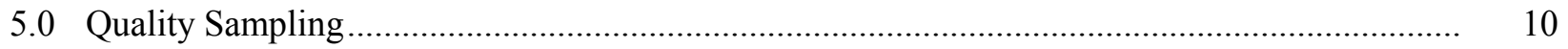

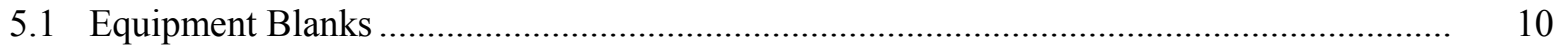

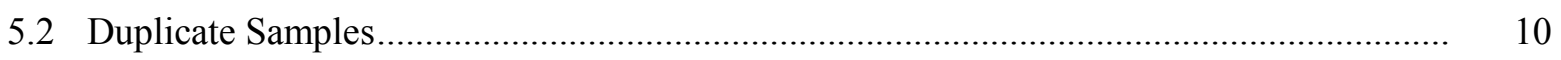

6.0 Reference

Appendix A - Soil and Groundwater Remediation Project Operating Procedure
GRP-FS-04-G-004: Operational Monitoring Groundwater Sampling..................... A.1

Appendix B - Groundwater Well Construction Documentation ................................................ B. B. 


\section{Figures}

1 Sampling Head with Silicone Tubing Extending Outward Radially from Central Siphon .......... 2

2 Modified Spyder Sampler with Drop Tube Assembly............................................................ 2

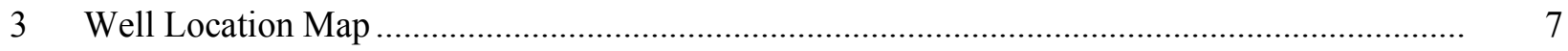

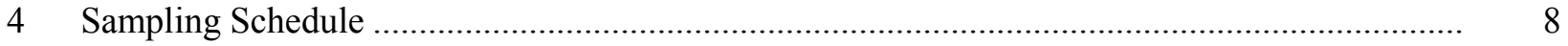

5 Spyder Sampler Attached to the Bottom of a QED 1250 Bladder Pump ................................. 9

\section{Tables}

1 Depth-Discrete Sample Locations, Intervals, and Constituent Requirements ............................ 4

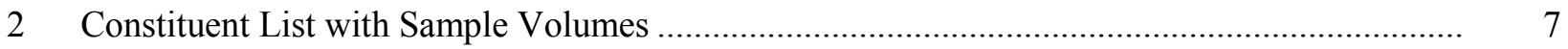




\subsection{Introduction}

The Discrete Groundwater Sampling Project conducted by the Pacific Northwest National Laboratory (PNNL) on behalf of CH2M HILL Plateau Remediation Company (CHPRC) is focused on delivering groundwater samples from selected horizons within select groundwater wells residing in the 200-BP-5 Groundwater Operable Unit (200-BP-5 OU). The data obtained from these samples are expected to provide information for the Remedial Investigation/Feasibility Study (RI/FS) Work Plan (DOE/RL-200718 Rev 1.0) for the 200-BP-5 OU.

PNNL has adapted the Spyder sampler to obtain groundwater samples from discrete horizons within groundwater monitoring wells with the intent of capturing vertical contamination profiles within surrounding hydrologic units. The ability of the system to deliver samples from depth with low-flow and minimal disruption to the groundwater flow regime was tested in several deployments, including the SX tank farm in 1999 (Johnson and Chou 2001).

\subsection{Spyder Sampler Description}

The PNNL-developed Spyder sampling accessory is added to a pump intake to increase the percentage and volume of water obtained from the formation and filter pack while diminishing the vertical and well-bore contribution to the sample. It is a valuable tool if stagnant water is in portions of the well and if flow is predominantly horizontal through the well. In addition, the volumetric flux (the volume of water moving through the well per unit of time for a specific thickness) is used to determine the allowable extraction rate. Large vertical components may limit or preclude its effectiveness.

The Spyder device consists of a head with flexible tubing extending from the central collector (Figure 1). Angled cuts on the tube ends allow a seal against the well screen when the unit is lowered into place. The hydrodynamic shape minimizes disturbance to the well water and associated primary flow zones and patterns. Water enters primarily from the filter pack and the formation.

The Spyder sampler is coupled to a bladder pump for low-flow (20 to $30 \mathrm{~mL} / \mathrm{min}$ ) sampling. The inlet device consists of a radial array of 12 flexible, small-bore (1/16-in.) silicone tubes attached to the inlet port of a bladder pump with a centralizer. The silicone tubes make contact with the interior wall of the well screen. Nominally $1 \mathrm{~L}$ of water is removed to flush the sample line prior to sample collection. The low pumping rate and inlet configuration are designed to minimize vertical disturbance of the aquifer during sample withdrawal so that a discrete depth sample is obtained. The bladder pump allows larger sample volumes to be obtained if required for certain analytical procedures. A minimum water level of $18 \mathrm{in}$. is required to fully cover the bladder pump before water can be driven from depth to the surface.

The weight of the water column deeper than $285 \mathrm{ft}$ below ground surface (bgs) is greater than the pressure limits of pump controller and bladder pump (125 psi for the currently deployed system). A modified Spyder sampling arrangement (Figure 2) for achieving depths in excess of $285 \mathrm{ft}$ bgs requires the use of chlorinated polyvinyl chloride (CPVC) pipe extensions up to $25 \mathrm{in}$. in length mounted on the intake end of the bladder pump. The drop tube method has been used to achieve groundwater depths in excess of $500 \mathrm{ft}$ bgs. 


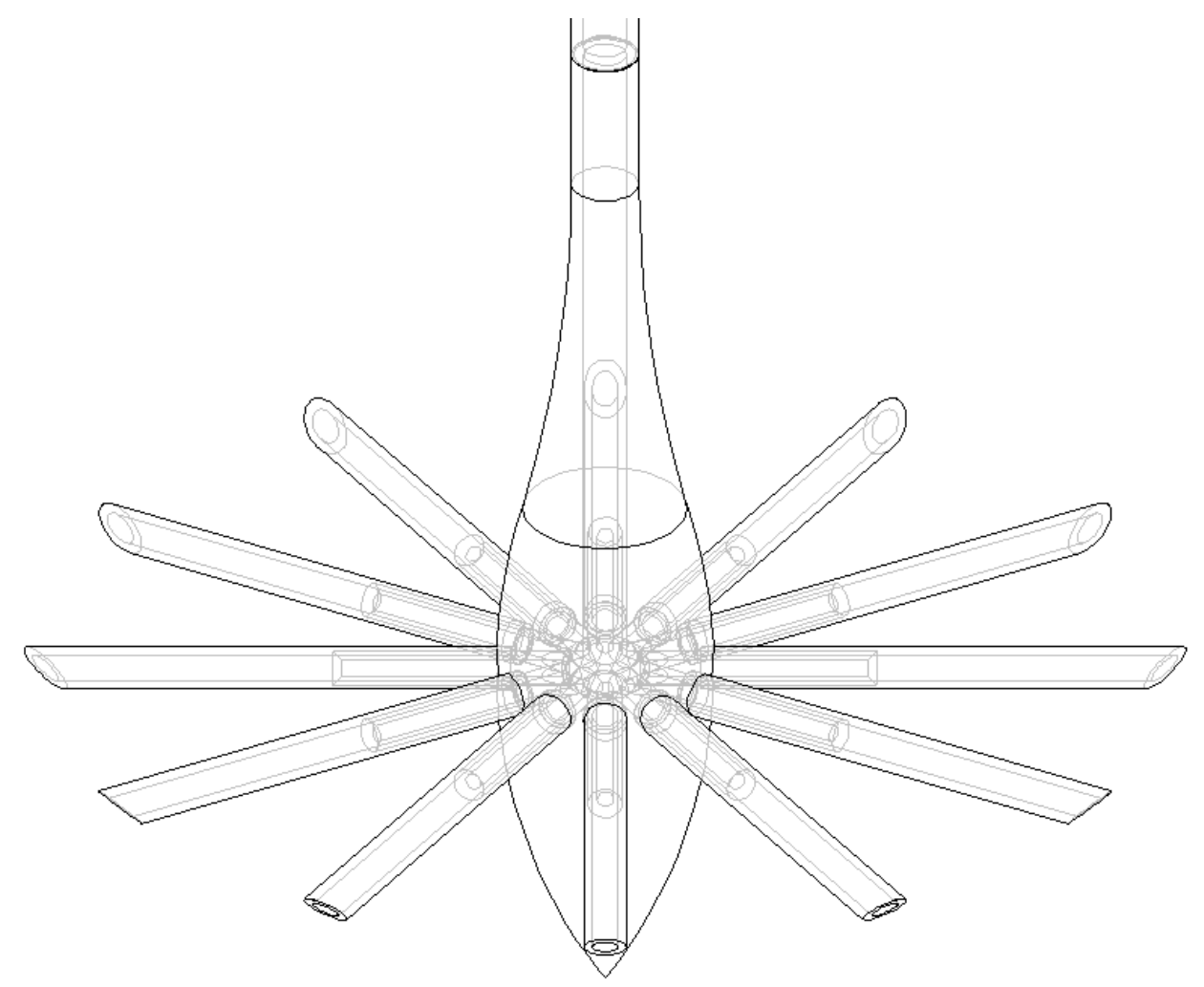

Figure 1. Sampling Head with Silicone Tubing Extending Outward Radially from Central Siphon

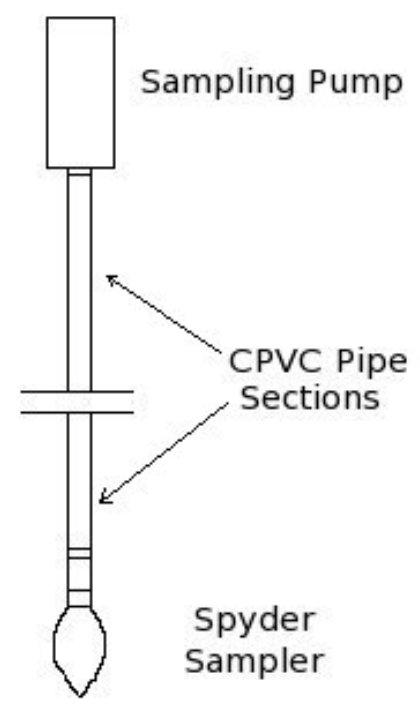

Figure 2. Modified Spyder Sampler with Drop Tube Assembly 


\subsection{Well Sampling}

The Spyder sampler will be used to sample discrete horizons within 14 active groundwater monitoring wells in the 200-BP-5 groundwater OU. Table 1 lists the wells to be sampled for this project, as well as the analytes and horizons selected for each well. The schedule for sampling each well is provided in Figure 2. The schedule provided is tentative due to cold-weather considerations.

\subsection{Well and Constitutent List}

Most of the wells to be sampled are located on the Central Plateau of the Hanford Site; two wells are located in the channel between Gable Mountain and the Central Plateau (Figure 3). All wells reside within the 200-BP-5 OU. The constituents are based on regularly observed elevated radionuclide and nitrate concentrations within these wells. Groundwater field parameters are also part of this list and include $\mathrm{pH}$, specific conductance, temperature, and turbidity. The volume of groundwater required for each analyte is included in Table 2.

\subsection{Schedule}

The schedule provided in Figure 4 indicates how PNNL staff plan to sample all of the horizons listed in Table 1 in the allotted time. The schedule displayed contains no regard for problems in sampling due to cold weather. The tubing used to deliver the samples from depth to the ground surface and ultimately into the prepared sample container is narrow enough that temperatures below $0^{\circ} \mathrm{C}$ could hinder sampling for either the early morning hours or perhaps for an entire day. Rescheduling sampling will be coordinated between the CHPRC technical point of contact and the PNNL manager for the Discrete Groundwater Sampling Project, or their respective delegates.

\subsection{Sampling}

The influence of the type of extraction method, the point of extraction relative to preferential flow zone(s), the rate of extraction, the volume extracted, and the point of discharge (i.e., sampling collection point) are key to knowing where the water came from and what it actually represents relative to the open interval. Once the flow conditions within the well are known, the concentration distribution in the well can be evaluated through discrete interval sampling and, where necessary, time-series sampling. Conventional groundwater sample collection from monitoring wells usually requires two steps or cycles. The first is purging, followed by the second step—sampling.

Well purging is the removal of a desired amount of groundwater before samples are collected for laboratory analysis. The purpose of purging is to ensure that the water samples obtained are representative of the chemical concentrations in the surrounding aquifer. The importance and necessity for well purging to obtain representative samples or measurements is based on the assumption that water quality in the screened interval of the monitoring well-is not representative of that in the immediate surrounding formation. 
Table 1. Depth-Discrete Sample Locations, Intervals, and Constituent Requirements

\begin{tabular}{|c|c|c|c|c|c|c|}
\hline Well Name & Constituents $^{(\mathrm{a})}$ & $\begin{array}{c}\text { Groundwater } \\
\text { Depth } \\
\text { (ft bgs) }\end{array}$ & $\begin{array}{l}\text { Screen Interval } \\
\quad(\mathrm{ft} \text { bgs })\end{array}$ & $\begin{array}{l}\text { Sediment Description } \\
\text { (ft bgs) }\end{array}$ & $\begin{array}{l}\text { Discrete } \\
\text { Sample } \\
\text { Interval } \\
\text { (ft bgs) }\end{array}$ & $\begin{array}{l}\text { Discrete } \\
\text { Sample } \\
\text { Interval } \\
\text { (m bgs) }\end{array}$ \\
\hline \multirow[t]{4}{*}{$699-50-56$} & \multirow[t]{4}{*}{$\mathrm{T}, \mathrm{N}, \mathrm{CN}, \mathrm{H}-3$} & \multirow[t]{4}{*}{152.1} & \multirow[t]{4}{*}{$151.2-161.2$} & $151.5-155$ gravelly silty sand & 153 & 46.6 \\
\hline & & & & 155-160 sandy gravel & 158 & 48.2 \\
\hline & & & & $160-161$ silty sandy gravel & 161 & 49.1 \\
\hline & & & & 161 basalt & & \\
\hline \multirow[t]{5}{*}{$699-53-55 \mathrm{C}$} & \multirow[t]{5}{*}{$\mathrm{T}, \mathrm{N}, \mathrm{CN}, \mathrm{H}-3, \mathrm{~S}$} & \multirow[t]{5}{*}{179.1} & \multirow[t]{5}{*}{$199.6-220.5$} & 190-205 sand, silt, and gravel & 199.6 & 60.8 \\
\hline & & & & 205-210 silt, sand, and gravel & 209 & 63.7 \\
\hline & & & & $210-213$ coarse sand and gravel & 212 & 64.6 \\
\hline & & & & $213-215$ fine silt & 214 & 65.2 \\
\hline & & & & 215-220.5 large gravel, cobble to 5 in. & 220 & 67.1 \\
\hline \multirow[t]{3}{*}{$\begin{array}{l}\text { 299-E33- } \\
342\end{array}$} & \multirow[t]{3}{*}{$\mathrm{U}, \mathrm{T}, \mathrm{N}, \mathrm{CN}, \mathrm{H}-3, \mathrm{~S}$} & \multirow[t]{3}{*}{235.8} & \multirow[t]{3}{*}{$232.6-242.6$} & $230-236$ sandy gravel & & \\
\hline & & & & 236-240 gravelly silty sand & 236.5 & 72.1 \\
\hline & & & & $240-242.4$ silty sandy gravel & 242.4 & 73.9 \\
\hline \multirow[t]{5}{*}{$\begin{array}{c}\text { 299-E33- } \\
343\end{array}$} & \multirow[t]{5}{*}{$\mathrm{U}, \mathrm{T}, \mathrm{N}, \mathrm{CN}, \mathrm{H}-3, \mathrm{~S}$} & \multirow[t]{5}{*}{252.14} & \multirow[t]{5}{*}{$249.9-259.9$} & $241-256$ gravelly sand & 253 & 77.1 \\
\hline & & & & $241-256$ gravelly sand & 255.5 & 77.9 \\
\hline & & & & 256-260.9 silty sandy gravel & 257.5 & 78.5 \\
\hline & & & & 256-260.9 silty sandy gravel & 260.7 & 79.5 \\
\hline & & & & 260.9 basalt & & \\
\hline \multirow[t]{4}{*}{$\begin{array}{l}\text { 299-E33- } \\
345\end{array}$} & \multirow[t]{4}{*}{$\mathrm{U}, \mathrm{T}, \mathrm{N}, \mathrm{CN}, \mathrm{H}-3, \mathrm{~S}$} & \multirow[t]{4}{*}{253.38} & \multirow[t]{4}{*}{$249.7-259.7$} & $250-255$ gravelly silty sand & 254 & 77.4 \\
\hline & & & & 255-260 sandy gravel & 256 & 78.0 \\
\hline & & & & 260-260.3 gravel & 260.1 & 79.3 \\
\hline & & & & 260.3 basalt & & \\
\hline \multirow[t]{3}{*}{$\begin{array}{l}\text { 299-E33- } \\
339\end{array}$} & \multirow[t]{3}{*}{$\mathrm{T}, \mathrm{N}, \mathrm{H}-3$} & \multirow[t]{3}{*}{263.4} & \multirow[t]{3}{*}{$259.4-279.3$} & $260-275$ sandy gravel & 265 & 80.8 \\
\hline & & & & 260-275 sandy gravel & 270 & 82.3 \\
\hline & & & & $260-275$ sandy gravel & 275 & 83.8 \\
\hline
\end{tabular}




\begin{tabular}{|c|c|c|c|c|c|c|}
\hline Well Name & Constituents $^{(\mathrm{a})}$ & $\begin{array}{l}\text { Groundwater } \\
\text { Depth } \\
(\mathrm{ft} \mathrm{bgs})\end{array}$ & $\begin{array}{l}\text { Screen Interval } \\
\quad(\mathrm{ft} \text { bgs })\end{array}$ & $\begin{array}{l}\text { Sediment Description } \\
\text { (ft bgs) }\end{array}$ & $\begin{array}{l}\text { Discrete } \\
\text { Sample } \\
\text { Interval } \\
\text { (ft bgs) }\end{array}$ & $\begin{array}{l}\text { Discrete } \\
\text { Sample } \\
\text { Interval } \\
\text { (m bgs) }\end{array}$ \\
\hline & & & & 279 basalt & & \\
\hline 299-E33-49 & $\mathrm{T}, \mathrm{N}, \mathrm{H}-3$ & 266.5 & $263.5-283.5$ & $\begin{array}{l}223-270 \text { silty sandy gravel } \\
270-283.5 \text { sandy gravel } \\
270-83.5 \text { sandy gravel } \\
270-283.5 \text { sandy gravel } \\
283.5 \text { basalt }\end{array}$ & $\begin{array}{c}265 \\
270 \\
276.5 \\
283.2\end{array}$ & $\begin{array}{l}80.8 \\
82.3 \\
84.3 \\
86.3\end{array}$ \\
\hline 299-E33-39 & $\mathrm{T}, \mathrm{N}, \mathrm{CN}, \mathrm{H}-3, \mathrm{~S}$ & 223.8 & $208-229.2$ & $\begin{array}{l}190-229.0 \text { silty sandy gravel } \\
229.0-229.5 \text { sand } \\
229.5 \text { basalt }\end{array}$ & $\begin{array}{c}224.5 \\
229.25\end{array}$ & $\begin{array}{l}68.4 \\
69.9\end{array}$ \\
\hline 299-E33-31 & $\mathrm{U}, \mathrm{T}, \mathrm{N}, \mathrm{CN}, \mathrm{H}-3, \mathrm{~S}, \mathrm{Cl}$ & 247.5 & $235-255$ & $\begin{array}{l}220-255.6 \text { sandy gravel } \\
220-255.6 \text { sandy gravel } \\
255.6 \text { basalt }\end{array}$ & $\begin{array}{l}250.5 \\
255.5\end{array}$ & $\begin{array}{l}76.4 \\
77.9\end{array}$ \\
\hline 299-E27-4 & $\mathrm{T}, \mathrm{N}, \mathrm{H}-3, \mathrm{~S}$ & 272.3 & $270.3-305.3$ & $\begin{array}{l}255-272 \text { gravel } \\
272-311 \text { sandy gravel } \\
272-311 \text { sandy gravel } \\
272-311 \text { sandy gravel }\end{array}$ & $\begin{array}{c}287 \\
297.5 \\
308\end{array}$ & $\begin{array}{l}87.5 \\
90.7 \\
93.9\end{array}$ \\
\hline 299-E27-7 & $\mathrm{T}, \mathrm{N}, \mathrm{H}-3, \mathrm{~S}, \mathrm{Cl}$ & 237 & $241-281$ & $\begin{array}{l}235-250 \text { fine sand and gravel } \\
235-250 \text { fine sand and gravel } \\
250-260 \text { gravel, fine sand Ringold FM } \\
260-275 \text { fine sand, gravel Ringold FM } \\
250-260 \text { gravel, fine sand Ringold FM } \\
275-280 \text { Ringold FM }\end{array}$ & $\begin{array}{c}242.5 \\
249.5 \\
255 \\
265 \\
275\end{array}$ & $\begin{array}{l}73.9 \\
76.0 \\
77.7 \\
80.8 \\
83.8\end{array}$ \\
\hline 299-E27-21 & $\mathrm{T}, \mathrm{N}, \mathrm{H}-3, \mathrm{~S}, \mathrm{Cl}$ & 273 & $271.4-306.4$ & $\begin{array}{l}275-285 \text { gravelly sand } \\
275-285 \text { gravelly sand } \\
285-318 \text { sandy gravel } \\
285-318 \text { sandy gravel }\end{array}$ & $\begin{array}{l}275 \\
285 \\
295 \\
305\end{array}$ & $\begin{array}{l}83.8 \\
86.9 \\
89.9 \\
93.0\end{array}$ \\
\hline 299-E27-10 & $\mathrm{T}, \mathrm{N}, \mathrm{S}, \mathrm{Cl}$ & 225 & $212.1-232.4$ & $\begin{array}{l}220-230 \text { silty sandy gravel } \\
230-233 \text { sand }\end{array}$ & $\begin{array}{c}227 \\
232.2\end{array}$ & $\begin{array}{l}69.2 \\
70.8\end{array}$ \\
\hline
\end{tabular}




\begin{tabular}{|c|c|c|c|c|c|c|}
\hline Well Name & Constituents $^{(a)}$ & $\begin{array}{l}\text { Groundwater } \\
\text { Depth } \\
\text { (ft bgs) }\end{array}$ & $\begin{array}{l}\text { Screen Interval } \\
\quad \text { (ft bgs) }\end{array}$ & $\begin{array}{l}\text { Sediment Description } \\
\text { (ft bgs) }\end{array}$ & $\begin{array}{l}\text { Discrete } \\
\text { Sample } \\
\text { Interval } \\
\text { (ft bgs) }\end{array}$ & $\begin{array}{l}\text { Discrete } \\
\text { Sample } \\
\text { Interval } \\
\text { (m bgs) }\end{array}$ \\
\hline & & & & \multicolumn{3}{|l|}{$233-240$ sandy gravel } \\
\hline & & & & \multicolumn{3}{|l|}{240 basalt } \\
\hline & & & & Total No. Samples & \multicolumn{2}{|r|}{48} \\
\hline & & & & Total No. Wells & \multicolumn{2}{|r|}{14} \\
\hline
\end{tabular}


Table 2. Constituent List with Sample Volumes

\begin{tabular}{lcl}
\hline Analyte & Sample Volume & Preservation \\
\hline Technetium-99 & $300 \mathrm{~mL}$ & $\mathrm{HCl}$ to $\mathrm{pH}<2$ \\
Nitrate & $125 \mathrm{~mL}^{\mathrm{a}}$ & $\mathrm{Cool} \sim 4^{\circ} \mathrm{C}$ \\
Cyanide & $250 \mathrm{~mL}$ & $\mathrm{Cool} \sim 4^{\circ} \mathrm{C}$ \\
Uranium & $300 \mathrm{~mL}$ & $\mathrm{HNO}_{3}$ to $\mathrm{pH}<2$ \\
Tritium & $500 \mathrm{~mL}$ & None \\
Sulfate & $125 \mathrm{~mL}^{\mathrm{a}}$ & $\mathrm{Cool} \sim 4^{\circ} \mathrm{C}$ \\
Chloride & $125 \mathrm{~mL}^{\mathrm{a}}$ & $\mathrm{Cool} \sim 4^{\circ} \mathrm{C}$ \\
\hline
\end{tabular}

(a) Nitrate, chloride, and sulfate all can be sampled from the same IC bottle $-125 \mathrm{~mL}$.

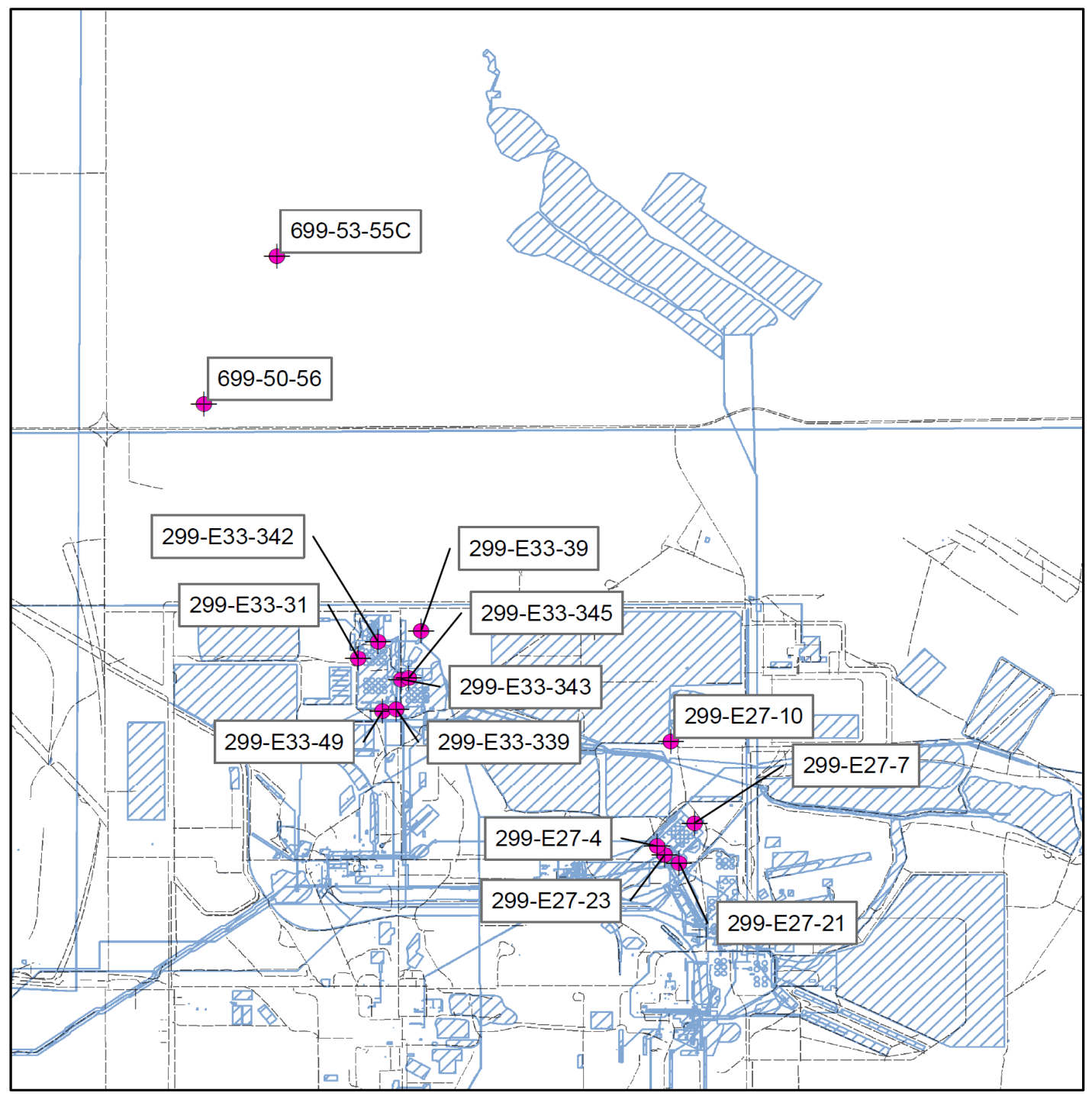

Figure 3. Well Location Map 


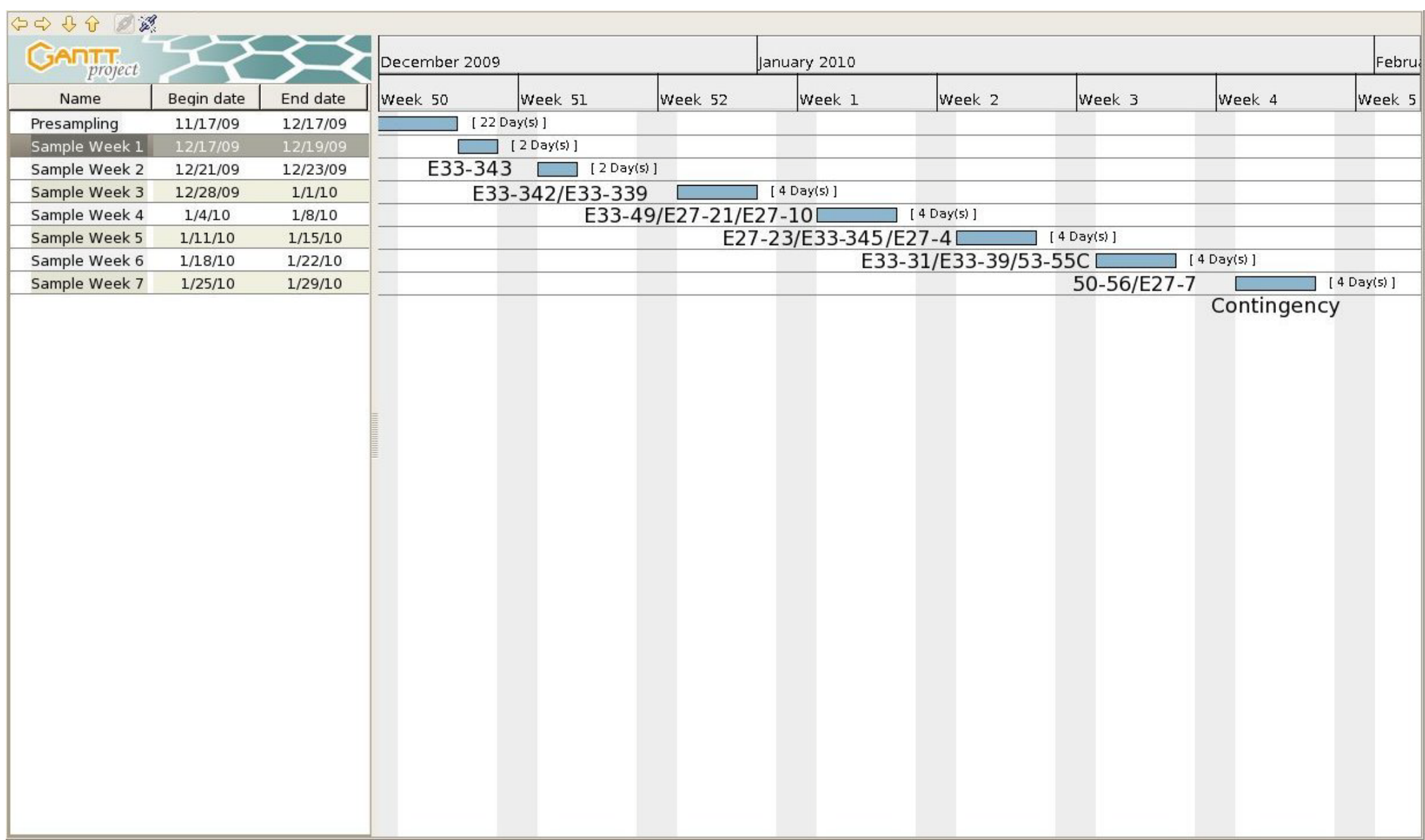

Figure 4. Sampling Schedule 
After the Spyder device is connected to the sampling port of the bladder pump as described in Section 2, the pump assemblage is lowered into the open borehole to the required depth in the aquifer (see Figure 5). Prior to the actual pumping event, sufficient time will be allowed to let disturbances in flow due to insertion into the water column to dissipate. The pump will be operated at flows lower than $300 \mathrm{~mL} / \mathrm{min}$, which will slowly raise the water column in the pump tubing to the surface.

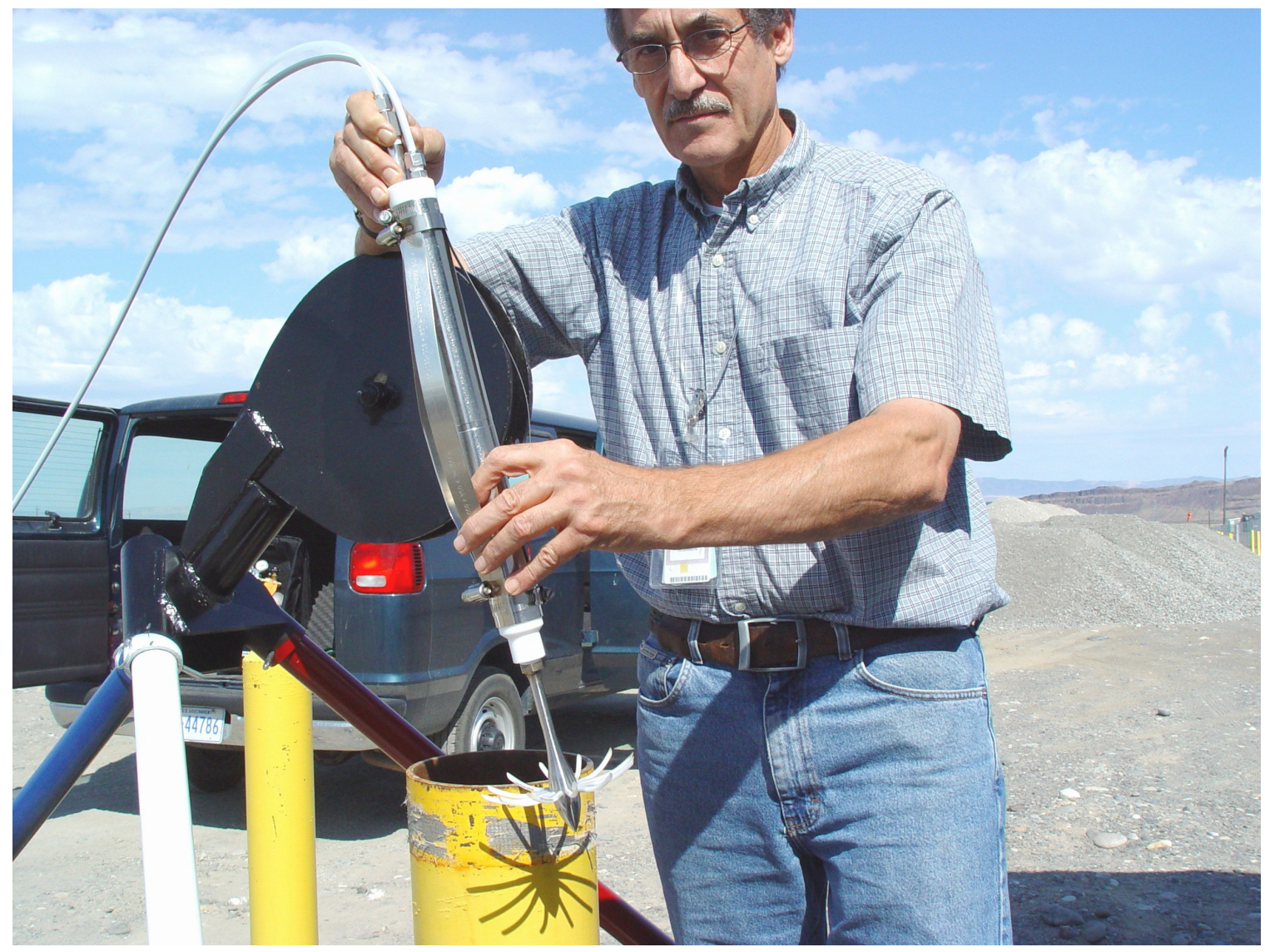

Figure 5. Spyder Sampler Attached to the Bottom of a QED 1250 Bladder Pump

The groundwater analytes to be sampled are outlined in Table 1, Section 3.1. Bottles will have been prepared (labeled and recorded in the chain-of-custody record for each well) for each well prior to sampling. The Spyder sampler pump will be started by slowly adding pressure through the hose assembly to the downhole pump from the compressed gas cylinder at the ground surface above. As the first groundwater arrives, it will be captured in a purge water container for later waste management (Section 4). As the water continues to flow, sampling technicians will obtain groundwater parameter readings to determine when to begin filling the sample containers. Guidance for sampling criteria is given in Appendix A.

As the sample bottles are filled, they will be placed in a storage container for transportation to the assigned laboratory. After the final sample bottle for the scheduled well is filled, the sample inventory will be compared to the data in Table 1 to ensure completeness, after which the samples will be shipped to the laboratory for analysis. Samples will be transported, stored, and delivered to the assigned laboratory per CHPRC procedures GRP-FS-04-G-012, "Sample Packaging and Shipping"; GRP-FS-04-G-016, 
"Chain of Custody/Sample Analysis Request"; GRP-FS-04-G-020, "Sample Storage Units"; and applicable HASQARD requirements.

Decontamination of the sample tubing will be completed after the last sample bottle is filled. Two PNNL staff members will decontaminate the riser tubing using rinse water brought from PNNL to the well each day of sampling. The sampler head and silicone tubing also will be decontaminated using the same water source. The water will be collected according to recommendations from CHPRC waste management staff. All purge and decontamination water will be released to CHPRC staff at the end of the sampling shift.

\subsection{Waste Management}

A CHPRC waste management coordinator has been assigned to aid in container selection and waste in the waste retention strategy. Cleaning sampling tubing that is in excess of $60 \mathrm{~m}$ will generate approximately $1.5 \mathrm{~L}$ of rinsate per well. The entire sampling process will generate approximately $10-15 \mathrm{~L}$ of purgewater and rinsate per well. The decontamination process will also generate wasteprotective glove wear and a minimum number of disposable towels.

\subsection{Quality Sampling}

\subsection{Equipment Blanks}

Equipment blanks will be gathered at the beginning of the first well and before sampling at specific wells highlighted in Table 1 (see footnotes).

\subsection{Duplicate Samples}

Three duplicate samples will be gathered to provide a basis for evaluating sampling and analysis conditions. The timing is highlighted in Table 1 (see footnotes).

\subsection{Reference}

Johnson VG and CJ Chou. 2001. RCRA Groundwater Quality Assessment Report for Waste Management Area S-SX (November 1997 through April 2000). PNNL-13441, Pacific Northwest National Laboratory, Richland, Washington. 


\section{Appendix A}

Soil and Groundwater Remediation Project

Operating Procedure GRP-FS-04-G-004:

Operational Monitoring Groundwater Sampling 



\title{
Soil and Groundwater Remediation Project
}

\author{
Operating Procedure
}

\section{GRP-FS-04-G-004 \\ Operational Monitoring Groundwater Sampling}

\author{
Revision: 1 \\ Change: D \\ Approval Designator: I, Q, R, W \\ Instruction Use Level: Reference
}

Approvals on file.

\author{
J. G. Hogan \\ Technical Authority \\ T. L. Reining \\ Field Work Supervisor \\ S. E. Hamaker \\ $\mathrm{NCO}$ (validator) \\ A. L. Foster \\ Safety Manager \\ R. Cook \\ T. E. Rainey \\ Electrical Design Authority \\ Design Authority \\ S. D. Landsman \\ J. D. Mehrer \\ Radiological Control Manager \\ Geosciences \\ M. Vermillion \\ Waste Management \\ Thackaberry \\ EQA \\ S. F. Conley \\ Sampling Operations Manager
}

Release Date: 07/01/2009 


\section{Table of Contents}

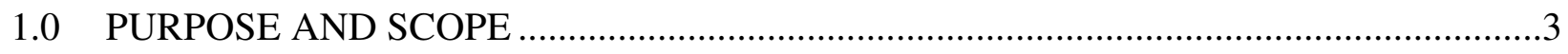

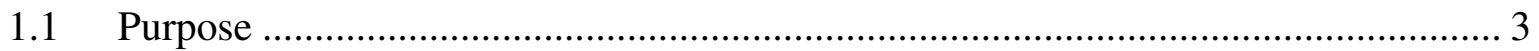

1.2 Scope

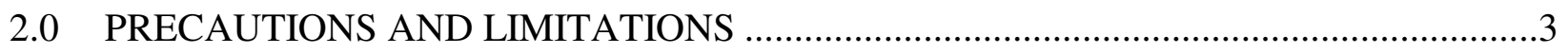

3.0 SPECIAL TOOLS, EQUIPMENT, AND MATERIALS ...............................................

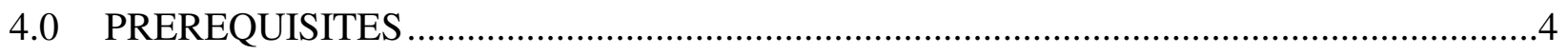

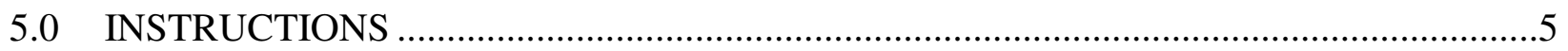

$5.1 \quad$ Preparation for Field Sampling ........................................................................... 5

5.2 Sampling Activities .................................................................................... 6

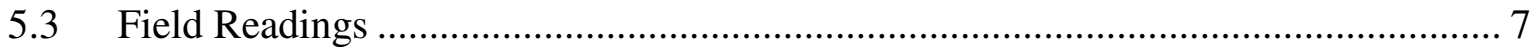

5.4 Post Sampling Activities................................................................................... 9

5.5 Waste Management............................................................................................ 10

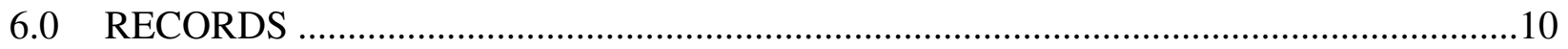

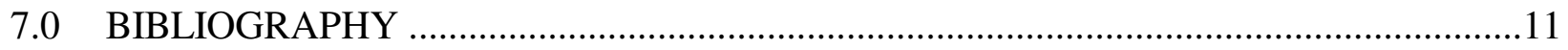

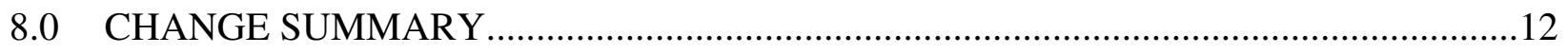

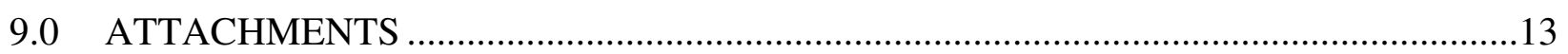

Attachment 1 - Sample Collection Using the Submersible Pump......................................... 14

Attachment 2 - Sample Collection Using Hydro Star Pump .............................................. 15

Attachment 3 - Sample Collecting Using Grundfos Redi-FLO 2 Sample Pumps .............. 16

Attachment 4 - Grab Sample Collection (i.e. Bailer, Kabis, weighted bottle) ..................... 18

Attachment 5 - Sample Collection from a Piezometer Using the Air Lift Method............. 19

Attachment 6 - Solinst Discrete Interval Sampler.......................................................... 20

Attachment 7 - Sample Collection Using a Peristaltic Pump........................................... 22

Attachment 8 - Extraction (Pump and Treat) Well Sample Collection................................. 23

Attachment 9 - Purge Flow Diagram............................................................................... 24 


\subsection{PURPOSE AND SCOPE}

\section{1 $\quad \underline{\text { Purpose }}$}

This procedure provides general requirements and guidance for performing groundwater sampling by Groundwater Operations (GWO) groundwater monitoring personnel.

\section{$1.2 \underline{\text { Scope }}$}

This procedure is limited to technical sampling activities in which groundwater samples are collected for field or laboratory analyses.

\subsection{PRECAUTIONS AND LIMITATIONS}

2.1 All personnel will be familiar with and comply with site-specific safety requirements for access control.

2.2 If abnormal conditions are encountered call the Field Work Supervisor (FWS).

2.3 Do not sample downwind from sources of volatile organics (e.g., car or generator exhausts, open fuel tanks), these could potentially contaminate the sample. If such sources are unavoidable, record them in the logbook and Groundwater Sampling Report (GSR), site form A-6003-667.

2.4 Avoid direct contact with groundwater except with gloved hands (i.e., surgeons or similar type gloves). 


\subsection{SPECIAL TOOLS, EQUIPMENT, AND MATERIALS}

Using skill-of-the-craft and training, stock the sample vehicle with tools and equipment required to perform this procedure, including but not limited to the following:

3.1 Decontaminated sampling manifolds (1 per well)

3.2 Disposable $0.45 \mu \mathrm{m}$ filters

3.3 Peristaltic pump

3.4 Air compressor and generator

3.5 Hydro Star pneumatic cylinder

3.6 Required Instruments

3.7 E-tape (water level measurement device)

3.8 High purity water

3.9 Field logbook

3.10 Groundwater Sampling Report (GSR), site form A-6003-667

3.11 Appropriate PPE

\subsection{PREREQUISITES}

4.1 Personnel using this procedure must be certified or under the direct supervision of a certified person to perform this procedure.

4.2 Sampling equipment shall be cleaned prior to use, in accordance with GRP-FS-04-G-013, Laboratory Cleaning of Sampling Equipment.

4.3 Sample containers used for chemical analysis shall be drawn from controlled storage area to ensure certified clean prior to use.

4.4 Review AJHA.

4.5 Review applicable MSDS.

4.6 Before initiating any field sampling activities, meet with all field sampling personnel and review all safety precautions and radiation, health, safety monitoring requirements, and QA/QC requirements (i.e. Trip Blank, FXR).

4.7 Review the most current "S\&GRP Well Waste Spreadsheet" as provided by the FWS to locate the well number(s) identified to be sampled in an operable unit prior to sampling.

4.8 Review the Groundwater Sample Report; GRP-FS-04-G-016, Chain of Custody/Sample Analysis Request; and other potential information such as notes, special directions, or point-of-contacts.

4.9 Check out instruments from storage (i.e., pH, conductivity, etc.) in accordance with GRPFS-04-G-005, Control of Monitoring Instruments. 


\subsection{INSTRUCTIONS}

\subsection{Preparation for Field Sampling}

\subsubsection{Field Work Supervisor:}

a. REVIEW sampling documents (e.g. COCs, sample labels, SAF, sampling matrix, Groundwater Sampling Report (GSR)) and any other project information that will provide direction for or assistance with meeting project requirements.

b. ASSIGN sampling paperwork and sampling task preparation to sampling personnel.

c. SCHEDULE sampling personnel to support the sampling event(s).

\subsubsection{Nuclear Chemical Operator:}

- REVIEW sampling documents including COCs, GSR, and sample labels for sampling event(s).

- ENSURE that appropriate sample containers are prepared and staged for sampling to be performed.

- IF there is a conflict between any sampling documents regarding container type or size, THEN CONTACT the FWS.

- STAGE AND ASSEMBLE equipment required for sampling and field data collection (label bottles, preservatives, coolers, ice, etc.).

- READ AND BECOME FAMILIAR with applicable project specific safety documents (i.e. HASP, AJHA, JSA, etc.).

- CONTACT appropriate person in charge of sample site (i.e. BTR, Facility Manager, FWS, PIC).

- INITIATE field logbook/Data Forms entry including: day, date and time task started, weather conditions and names and titles and organizations of personnel performing the task.

- ENSURE initial performance checks of field instruments are complete and recorded in field logbook. 


\section{Note}

If possible, park adjacent to the well at a right angle to the wind with rear of van facing the well head.

\subsection{Sampling Activities}

- $\quad$ PARK vehicle near well for safe operation of sampling equipment.

- $\quad$ ESTABLISH a control area around well.

- MONITOR and CONTROL area around wells as necessary to protect personnel from injury and prevent damage to equipment.

- Verbally COMMUNICATE or physically ESTABLISH control area using caution tape or equally effective means.

- $\quad$ VERIFY that the documentation (i.e. GSR) matches the well name.

- DETERMINE appropriate sampling method.

- $\quad$ DON appropriate PPE per task, as needed.

- $\quad$ RECORD instrument pre-check for $\mathrm{pH}$ and conductivity on the GSR.

- RECORD lot numbers of sample containers on GSR and/or in field logbook.

- $\quad$ MEASURE depth to water from the designated measurement point, AND RECORD measurement, to nearest $1 \mathrm{~mm}$, on GSR and/or field logbook, and Groundwater Measurement form.

- $\quad$ CHECK for a sheen or oil product while cleaning tape.

- IF sheen or oil product is present, THEN RECORD information on GSR or in field logbook.

5.2.1 INITIATE sampling method and set-up using applicable attachment.

\section{Note}

Purge volumes are usually based on pumping 3 borehole volumes of water from the well. The customer may direct a specific purge volume.

5.2.2 CALCULATE purge time (if not provided by customer) as follows:

a. DETERMINE the flow rate. 
b. DIVIDE purge volume given for that well by flow rate.

5.2.3 RECORD purge time (in minutes) on GSR and/or in field logbook.

5.2.4 IF the well pumps dry, THEN TURN off the pump,

AND PERFORM the following:

a. TRACK recharge rate for 15 minutes.

b. IF well does not recharge,

THEN contact FWS.

c. IF well has recharged, THEN TURN pump back on, AND fill sample containers.

d. IF the well pumps dry during collection of samples, THEN REPEAT Steps a. through c.

\subsection{Field Readings}

\section{Note}

The readings shall stabilize prior to sampling and shall be considered "stable" when the following are met:

- $\mathrm{pH}$ - two consecutive measurements agree within $0.2 \mathrm{pH}$ units

- Temperature - two consecutive measurements agree within $0.2^{\circ} \mathrm{C}$

- Conductivity - two consecutive measurements agree within $10 \%$ of each other

- Turbidity - less than 5 NTUs prior to sampling (or project scientist's recommendation).

Dissolved oxygen and oxygen reduction potential are not indicator parameters and are not required to be stable prior to sample collection.

5.3.1 OBTAIN field readings at least three times (start, middle, and end of designated purge time),

AND RECORD readings on GSR.

\section{Note}

If a well is not purged, one set of field readings is sufficient unless directed otherwise on the GSR or by the FWS.

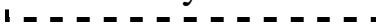


5.3.2 Before filling sample bottles, ENSURE purge requirements and required field readings have been met per GSR, Purge Flow Diagram (Attachment 9), or Project Scientist instruction.

5.3.3 FILL sample containers in the following order unless otherwise specified in the sampling plan:
a. Unfiltered volatile organics (VOAs)
b. Unfiltered total organic halogens (TOX)
c. Unfiltered total organic carbon (TOC)
d. Unfiltered semi-volatile organics (Semi-VOAs)
e. Other unfiltered glass containers (i.e., other organics)
f. Other unfiltered samples
g. Filtered samples (in the same order as items a. through f.)

5.3.4 IF sampling order is different from that specified above,

THEN RECORD sampling order and justification for order in field logbook and on GSR.

5.3.5 After filling last sample container,

MEASURE $\mathrm{pH}$, temperature, specific conductivity, and other requested field measurements,

AND RECORD on GSR.

\section{Note}

When removing portable pumps, if necessary request assistance.

5.3.6 CONCLUDE sampling activity, AND SECURE equipment.

5.3.7 ENSURE the following:

- Evidence tape has been signed, dated, and attached to container lid.

- Each sample label has been completely filled out by sampler.

- Bottles collected match what is listed on COC.

- Preservation requirements are met.

\section{Note}

Rinse water is to be handled as discarded water (i.e., purgewater).

5.3.8 RINSE sampling equipment coming in contact with groundwater being placed in sample containers or entering well (e.g., E-tapes, instrument probes, etc.) with highpurity water after sampling is completed. 
5.3.9 ENSURE well cap has been replaced and locked, AND ENSURE flush mounted wells are bolted down.

5.3.10 IF a well cannot be secured,

THEN immediately NOTIFY FWS.

5.3.11 CONDUCT post-performance checks of $\mathrm{pH}$ and conductivity, AND RECORD on GSR.

5.3.12 REMOVE AND DISCARD PPE and well waste into waste container when sampling is complete.

\subsection{Post Sampling Activities}

5.4.1 ENSURE completion of COC/SAR, GSR and field logbook; field logbook to include:

- Details of equipment failures

- Breakdowns or unusual occurrences related to the sampling activity

- The sampler signature and date at the bottom of each page

5.4.2 REQUEST independent review of COC forms, sample labels, GSR, and logbook after completion (one over one check).

5.4.3 PLACE samples in a secure location during transportation.

5.4.4 IF sampling additional well, THEN RETURN to Step 5.2, OTHERWISE CONTINUE to Step 5.4.5.

5.4.5 ENSURE samples are packaged in accordance with GRP-FS-04-G-012, Operational Monitoring Sample Packaging and Shipping.

5.4.6 DELIVER sample to shipping personnel or appropriate laboratory for analysis as soon as possible.

5.4.7 IF sample(s) cannot be delivered the same day (due to time constraints or radiological laboratory screening, THEN store samples according to GRP-FS-04-G-020, Sample Storage Units AND contact FWS.

5.4.8 IF a portable Grundfos pump was used, THEN perform the following two substeps prior to returning pump to be cleaned:

a. FLUSH with potable water for 5 min with control-box set at approximately $200 \mathrm{~Hz}$ to obtain triple-rinse. 
b. DISPOSE of water into purge truck.

\subsection{Waste Management}

5.5.1 REFERENCE the "Well Waste Spreadsheet", MATCH the well name with the Operable Unit (OU) collection point, THEN deposit the waste at that OU collection point.

5.5.2 PRINT clearly and legibly when labeling waste.

5.5.3 LABEL/MARK the sample waste at a minimum with: well number, operable unit, date and operator's name.

5.5.4 IF the Well/Seep Name is not listed on the Well Waste Spreadsheet, THEN DEPOSIT waste at the RCRA Accumulation Area.

\subsection{RECORDS}

\begin{tabular}{|l|l|l|}
\hline \multicolumn{1}{|c|}{ Document } & \multicolumn{1}{|c|}{ Destination } & \multicolumn{1}{c|}{ Disposition } \\
\hline Field Logbooks & $\begin{array}{l}\text { S\&GRP Operations } \\
\text { secretary in charge of } \\
\text { records }\end{array}$ & Send to RHA as volume warrants \\
\hline Chain of Custody forms & $\begin{array}{l}\text { S\&GRP Operations } \\
\text { secretary in charge of } \\
\text { records }\end{array}$ & $\begin{array}{l}\text { Deliver to Sample and Data } \\
\text { Management }\end{array}$ \\
\hline $\begin{array}{l}\text { Groundwater Sample Record } \\
\text { (A-6003-667) }\end{array}$ & $\begin{array}{l}\text { S\&GRP Operations } \\
\text { secretary in charge of } \\
\text { records }\end{array}$ & $\begin{array}{l}\text { Deliver to Sample and Data } \\
\text { Management }\end{array}$ \\
\hline Water Level Measurement Form & $\begin{array}{l}\text { S\&GRP Operations } \\
\text { secretary in charge of } \\
\text { records }\end{array}$ & $\begin{array}{l}\text { Deliver to Sample and Data } \\
\text { Management }\end{array}$ \\
\hline
\end{tabular}


S\&GRP Operating Procedure

Operational Monitoring Groundwater Sampling
GRP-FS-04-G-004

Rev. 1, Chg. D

Page 11 of 24

\subsection{BIBLIOGRAPHY}

7.1 DOE/RL-96-68, HASQARD, Hanford Analytical Services Quality Assurance Requirements Documents

7.2 GRP-FS-04-G-005, Control of Monitoring Instruments

7.3 GRP-FS-04-G-006, Operate HACH 2100P Turbidimeter

7.4 GRP-FS-04-G-010, Operate Oxidation-Reduction Potential (ORP) Probe

7.5 GRP-FS-04-G-012, Operational Monitoring Sample Packaging and Shipping

7.6 GRP-FS-04-G-013, Laboratory Cleaning of Sampling Equipment

7.7 GRP-FS-04-G-014, Measurements of Groundwater Levels

7.8 GRP-FS-04-G-016, Chain of Custody/Sample Analysis Request

7.9 GRP-FS-04-G-020, Sample Storage Units

7.10 GRP-FS-04-G-041, Operate HQ40d/HQ30d Meter for $\mathrm{pH}$, Conductivity, and Dissolved Oxygen

7.11 HNF-20635, Groundwater Remediation Project Quality Assurance Project Plan (GRP-QA-001)

7.12 HNF-RD-210, Records Management Program

7.13 HNF-PRO-10863, Notebooks and Logbooks

7.14 OSWER-9950.1, RCRA Ground-water Monitoring Technical Enforcement Guidance Document (TEGD)

7.15 WAC 173-160, 1998, Minimum Standards for Construction and Maintenance of Wells 


\subsection{CHANGE SUMMARY}

\begin{tabular}{|c|c|c|c|c|}
\hline $\begin{array}{c}\text { Change } \\
\text { Level }\end{array}$ & $\begin{array}{l}\text { Change By/ } \\
\text { Document }\end{array}$ & Date & Pages & Description \\
\hline Rev. 1 & $\begin{array}{l}\text { GC Clark } \\
\text { DPASF } \\
12855\end{array}$ & $12 / 15 / 08$ & All & $\begin{array}{l}\text { Major Change (revision) to incorporate input } \\
\text { from NCOs. } \\
\text { AJHA No.: } \mathbf{G W - 5 2 4}\end{array}$ \\
\hline Chg. A & $\begin{array}{l}\text { GC Clark } \\
\text { DCF } 15171\end{array}$ & 01/05/09 & 6 & $\begin{array}{l}\text { Minor Technical Change to add the word } \\
\text { "initial" between ENSURE and performance } \\
\text { ino Step 5.1.2, } 8^{\text {th }} \text { bullet. }\end{array}$ \\
\hline Chg. B & $\begin{array}{l}\text { GC Clark } \\
\text { DCF } 15372\end{array}$ & $02 / 24 / 09$ & $\begin{array}{c}3,4,11 \text {, } \\
13,25\end{array}$ & $\begin{array}{l}\text { Minor Technical Change to: } \\
\text { 1) add site form no. to } 2.3 \text {; } \\
\text { 2) add new } 3.11 \text {; } \\
\text { 3) add site form no. to } 6.0 \text { RECORDS; } \\
\text { 4) delete Attachment } 10 \text { in } 9.0 \\
\text { ATTACHMENTS and page } 25 \text {. } \\
\text { No effect on AJHA. }\end{array}$ \\
\hline Chg. C & $\begin{array}{l}\text { JA Newbill } \\
\text { DCFs } \\
15386, \\
15460 \\
15471\end{array}$ & 03/11/09 & $\begin{array}{l}6,7,9 \\
11,15 \\
16,18 \\
23\end{array}$ & $\begin{array}{l}\text { Minor Technical Change to: } \\
\text { 1) Step 5.1.2, sixth bullet: change "logbook" } \\
\text { to "logbook/Data Forms". } \\
\text { 2) Change step 5.2, eighth bullet to read "GSR } \\
\text { and/or field logbook". } \\
\text { 3) Change step 5.3.3.e from "Other organics" } \\
\text { to "Other unfiltered glass containers (i.e., } \\
\text { other organics)". } \\
\text { 4) Section 6.0 Records table: } \\
\text { a) Delete S\&GRP Waste Inventory Sheet } \\
\text { and Continuation Page. } \\
\text { b) Add "S\&GRP" to Destination entries. } \\
\text { c) Change second, third and fourth } \\
\text { Disposition entries from "Send to RHA } \\
\text { as volume warrants" to "Deliver to } \\
\text { Sample and Data Management". } \\
\text { 5) Last step of attachments 1, 2, 3, and 7: } \\
\text { change section/step 5.2.11 to section/step } \\
\text { 5.2.2 (5.2.11 does not exist). } \\
\text { No effect on AJHA. }\end{array}$ \\
\hline Chg. D & $\begin{array}{l}\text { JA Newbill } \\
\text { CPRs } \\
16005 \\
16006\end{array}$ & 07/01/09 & 6,24 & $\begin{array}{l}\text { Minor Technical Change to: } \\
\text { 1) Section 5.2, second bullet; add sub-bullets. } \\
\text { 2) Attachment 9, second diamond (on right); } \\
\text { change "+/- 10\%" to "per step 5.3" }\end{array}$ \\
\hline
\end{tabular}




\subsection{ATTACHMENTS}

9.1 Attachment 1 - Sample Collection Using the Submersible Pump

9.2 Attachment 2 - Sample Collection Using the Hydro Star Pump

9.3 Attachment 3 - Sample Collection Using Grundfos Redi-Flo 2 Sample Pump

9.4 Attachment 4 - Grab Sample Collection

9.5 Attachment 5 - Sample Collection from a Piezometer Using the Air Lift Method

9.6 Attachment 6 - Sample Collection Using a Solinst Discrete Interval Sampler

9.7 Attachment 7 - Sample Collection Using a Peristaltic Pump

9.8 Attachment 8 - Extraction (Pump and Treat) Well Sample Collection

9.9 Attachment 9 - Purging Flow Diagram 


\section{Attachment 1 - Sample Collection Using the Submersible Pump}

1.0 ATTACH manifold and purge hose to well.

2.0 ENSURE power switch is in OFF position.

3.0 PLUG power cord into power source and at well head.

4.0 START electric generator AND ALLOW it to warm up, if not already running.

\section{Caution}

Do not handle power cords once they have been energized.

5.0 TURN power switch $\mathrm{ON}$ to begin pumping process.

IF pump does not work properly, as indicated by a lack of air flow out the drop leg or by generator 'lug' down, THEN TURN the switch off immediately, AND PERFORM the following:

5.1 WAIT a few seconds, THEN TURN the switch ON, AND WAIT to see/hear if pump starts.

\section{Note}

- This next step is only necessary on older, electric submersible pumps and will not always be necessary to start the pump.

- Pausing 15 to 30 seconds between switching "on" and "off" allows breaker trip elements to cool.

5.2 IF the pump does not start,

THEN TURN the power switch ON and OFF a few times, Allowing 15 to 30 seconds between each cycle, finally pausing in the ON position if the pump has started.

5.3 IF a breaker trips or a fuse is blown on the generator, THEN TURN power switch to OFF position, AND RESET breaker or fuse as needed.

5.4 DISCONTINUE sampling, RECORD in GSR/logbook, AND NOTIFY FWS.

6.0 After water begins to flow from outlet, RETURN to Section 5.2.2 for calculating purge time. 


\section{Attachment 2 - Sample Collection Using Hydro Star Pump}

\section{Note}

Pump is to be operated at up to 2 gpm unless otherwise specified.

1.0 ATTACH manifold and purge hose to well.

2.0 ATTACH pneumatic cylinder assembly (Actuator) to well head assembly.

\section{Caution}

- Ensure at least 2 holes on the cylinder support overlap with 2 hole on column support. Also, ensure cylinder rod is fully extended before attaching actuator rod.

- Actuator is top heavy, use caution when handling - request assistance if necessary.

3.0 ATTACH quick connect on air supply hose to unattached end of control valve on pneumatic cylinder. The input air pressure should not exceed 120 psi.

\section{Note}

Air compressor may not start, if air tank is pressurized. Open drain valve to depressurize tank.

4.0 START air compressor.

5.0 TURN on control valve on pneumatic cylinder. The piston will begin to operate.

6.0 ADJUST the stroke rate to obtain no more than $2 \mathrm{gpm}$ using the control valve located on the top of pneumatic cylinder .

7.0 After water begins to flow from outlet, RETURN to Section 5.2.2 for calculating purge time. 


\section{Attachment 3 - Sample Collecting Using Grundfos Redi-FLO 2 Sample Pumps}

(Page 1 of 2)

\section{Note}

Pump is to be operated at up to 2 gpm unless otherwise specified.

1.0 IF Redi-Flo 2 pump has been permanently installed, THEN GO-TO step 6.0.

2.0 ENSURE that the Portable Redi-Flo 2 pump has decontamination tag attached (signed and dated). IF no tag, do not use.

3.0 INSTALL portable Redi-Flo 2 pump using one of the following methods:

- FOLLOW GSR recommendations as to how deep the Redi-Flo 2 pump is to be installed

- LOWER pump to well bottom THEN RAISE pump to approximately 2 feet from well bottom.

4.0 LATCH reel in place to secure pump at proper depth.

5.0 CONNECT sample manifold to discharge outlet.

\section{Caution}

The Redi-Flo 2 control box is not rated for outdoor use; it should be kept in the sample van.

6.0 CONNECT Redi-Flo 2 control box to dedicated electrical source and pump reel (or electrical connector of permanently installed pump).

7.0 START electric generator $\underline{\text { AND }}$ ALLOW it to warm up, if not already running.

\section{Caution}

Do not handle power cords once they have been energized.

8.0 START the Redi-Flo 2 pump,

$\underline{\text { AND }}$ adjust to obtain desired flow rate.

9.0 IF pump does not work properly, as indicated by a lack of air flow out the drop leg or by generator 'lug' down,

THEN TURN the Redi-Flo 2 control box off immediately, AND PERFORM the following: 
Attachment 3 - Sample Collecting Using Grundfos Redi-FLO 2 Sample Pumps

(Page 2 of 2)

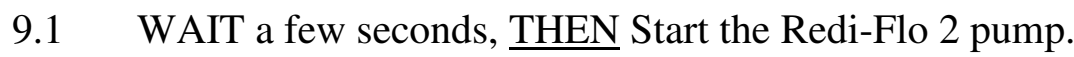

9.2 ADJUST to obtain desired flow rate, AND WAIT to see/hear if pump starts.

\section{Note}

Pausing 15 to 30 seconds between switching "on" and "off" allows breaker trip elements to cool.

9.3 IF the pump does not start,

THEN Start and stop the Redi-Flo 2 pump a few times,

Allowing 15 to 30 seconds between each cycle,

finally pausing in the ON position if the pump has started.

9.4 IF a breaker trips or a fuse is blown on the generator,

THEN TURN power switch to OFF position,

AND RESET breaker or fuse as needed.

9.5 DISCONTINUE sampling.

9.6 RECORD in the GSR and/or logbook.

\subsection{NOTIFY FWS.}

10.0 IF pump stops, THEN OBSERVE indicators on digital display, AND notify FWS.

11.0 After water begins to flow from outlet, RETURN to Section 5.2.2 for calculating purge time. 
Attachment 4 - Grab Sample Collection (i.e. Bailer, Kabis, weighted bottle)

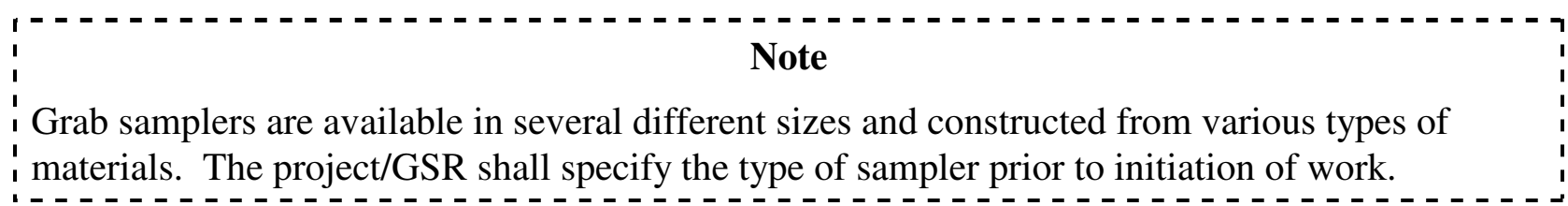

1.0 ENSURE a laboratory cleaned bailer or field decontaminated sampler is used.

2.0 ATTACH a rope or wire to the sampler.

3.0 Slowly LOWER the bailer into the water.

\section{Caution}

Never drop the sampler into the well, doing so may cause degassing of volatile organics or increase turbidity.

4.0 STOP at appropriate depth and allow sampler to fill.

5.0 RAISE the sampler to the surface.

\section{Note}

Water should be poured directly from the sampler into the sample container slowly to prevent

trapping any air bubbles (VOA samples).

6.0 AVOID splashing or agitating the water while the sample container is being filled.

7.0 RECORD sample temperature, $\mathrm{pH}$, turbidity, and conductivity (or other measurements, as requested), on the GSR or in the field logbook.

8.0 RETURN to Step 5.3.3, "Fill sample containers ..." 


\section{Attachment 5 - Sample Collection from a Piezometer Using the Air Lift Method}

\section{Note}

Some piezometer tubes are sampled by the airlift method where the sample water is pushed up and out of the well by compressed air; an ABS tube has been installed in these wells for this purpose.

1.0 CONNECT airline to main compressor fitting on sample vehicle.

2.0 ENSURE all valves are closed on 3-way valve.

3.0 CONNECT air line to 3-way valve.

4.0 CONNECT 3-way valve to well head fitting.

5.0 CONNECT sample manifold/drop-leg to piezometer tube.

6.0 START compressor.

\section{Note}

When adjusting regulator, turning the valve clockwise increases pressure while turning the valve counter clockwise reduces pressure. A minimum of $100 \mathrm{psi}$ with a maximum of $125 \mathrm{psi}$ is required to produce water to the surface.

\section{Caution}

Due to the pressurizing of the ABS pipe, do not stand over well head.

7.0 SET output on discharge gauge to a minimum of 100 psi.

8.0 OPEN the air supply valve.

9.0 ALLOW piezometer to reach pressure. IF water reaches surface, THEN COLLECT as part of purge.

10.0 ONCE flow has stopped, CLOSE pressure valve.

11.0 ALLOW piezometer to recharge 3 to 5 minutes.

12.0 REPEAT Steps 8.0 through 11.0 to continue purge as directed by GSR.

13.0 RECORD sample temperature, $\mathrm{pH}$, turbidity, and conductivity (or other measurements, as requested), on the GSR or in the field logbook.

14.0 COLLECT all sample water in clean secondary container.

15.0 RETURN to Step 5.3.3, "Fill sample containers ..." 


\section{Attachment 6 - Solinst Discrete Interval Sampler}

(Page 1 of 2)

\section{Caution}

Correct installation of O-rings and check balls are essential to the operation of the Solinst Sampler.

1.0 ASSEMBLE sampler, ensuring white colored ball on bottom and opaque ball on top.

2.0 ATTACH sampler to tubing reel,

AND TIGHTEN swagelok 1/4 turn past hand tight.

\section{Note}

Samples collected with the Solinst may require the use of a tripod or drill rig (with safety line).

3.0 Using the sample depth listed on GSR, DETERMINE pressure using the following table.

\begin{tabular}{|c|c|c|c|}
\hline \multicolumn{4}{|c|}{ Recommended Operating Pressure } \\
\hline Depth (feet) & Pressure (psi) & Depth (meters) & Pressure (kPa) \\
\hline 25 & 20 & 8 & 148 \\
\hline 50 & 30 & 15 & 217 \\
\hline 100 & 50 & 30 & 364 \\
\hline 200 & 95 & 60 & 660 \\
\hline 300 & 140 & 90 & 952 \\
\hline 500 & 225 & 150 & 1540 \\
\hline
\end{tabular}

Note: These are practical minimum pressures, and may be exceeded without adverse affect.

4.0 RECORD Operating Pressure on GSR for each sample interval.

5.0 HOLD the sampler vertically to allow the lower check valve to seat.

6.0 REMOVE the valve cap from the valve stem on the face of the tubing reel, AND ATTACH the hand pump to the valve stem.

7.0 TURN the valve selector to "pressurize", AND PRESSURIZE (with hand pump) the sampler to the calculated pressure for the depth being sampled

8.0 RECORD the pressure where indicated on the GSR. 


\section{Attachment 6 - Solinst Discrete Interval Sampler}

(Page 2 of 2)

9.0 DETACH the pump,

AND THEN lower the sampler to the target depth for sampling.

10.0 TURN the valve selector to "vent"

AND WAIT at least 1 minute for sampler to fill.

11.0 TURN the valve selector to "pressurize".

12.0 ATTACH the pump, AND PRESSURIZE the sampler to calculated pressure for this sampling depth.

13.0 DETACH the pump.

14.0 RECOVER the sampler from the well slowly by pulling the sampler out of the well and spooling tubing back onto the reel.

15.0 HOLD the sampler upright, AND TURN the valve selector to "vent" to release the pressure on the system.

16.0 INSERT the sample release device into the bottom end to release water and fill sample containers,

$\underline{\text { AND }}$ use remaining water to obtain required field readings.

17.0 As required, DISASSEMBLE the sampler AND RINSE all the pieces thoroughly with deionized water.

18.0 REPEAT process for each sample interval.

19.0 GO TO section 5.3.7. 


\begin{tabular}{|ll|}
\hline S\&GRP Operating Procedure & GRP-FS-04-G-004 \\
& Rev. 1, Chg. D \\
Operational Monitoring Groundwater Sampling & Page 22 of 24 \\
\hline
\end{tabular}

\section{Attachment 7 - Sample Collection Using a Peristaltic Pump}

The principal drawback of peristaltic pumps is they require disposable hose, which must be compatible with the media being sampled. In addition, this sampling method may be difficult for collecting representative samples of phased or graduated liquids, as the inlet end of the hose must be raised and lowered into the container at a very uniform rate. In addition, the completion of a raising or lowering cycle of the inlet end of the hose must coincide with the completion of filling the sample container.

\section{Procedure for Use}

1.0 If needed, PLACE a pump weight on the end of the hose so that the hose does not float on the liquid surface.

2.0 CONNECT tubing to the pump head.

3.0 PLACE an inlet hose into the liquid or connect to existing sample port, THEN ACTIVATE the pumping mechanism.

4.0 DRAW the sample through the inlet hose to a sample container.

5.0 DRAIN liquid in the inlet hose back into the container after pumping (a peristaltic pump can be run in reverse to empty the tubing back into the container).

6.0 GO TO Step 5.2.2. 


\section{Attachment 8 - Extraction (Pump and Treat) Well Sample Collection}

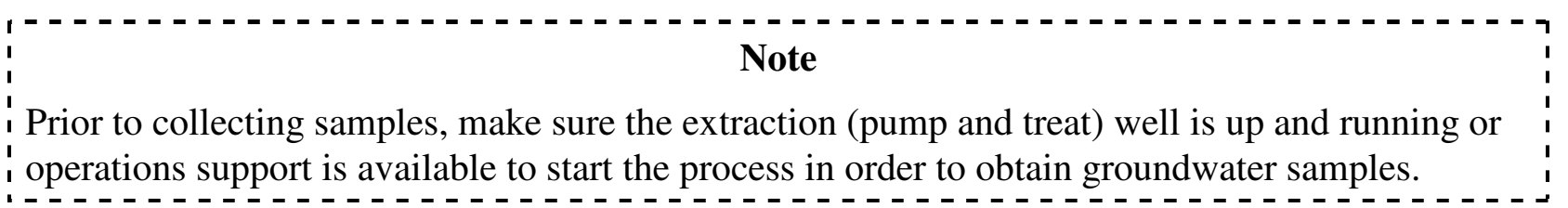

1.0 RECORD valve number.

2.0 RETURN to Section 5.3, "Field Readings". 


\section{Attachment 9 - Purge Flow Diagram}

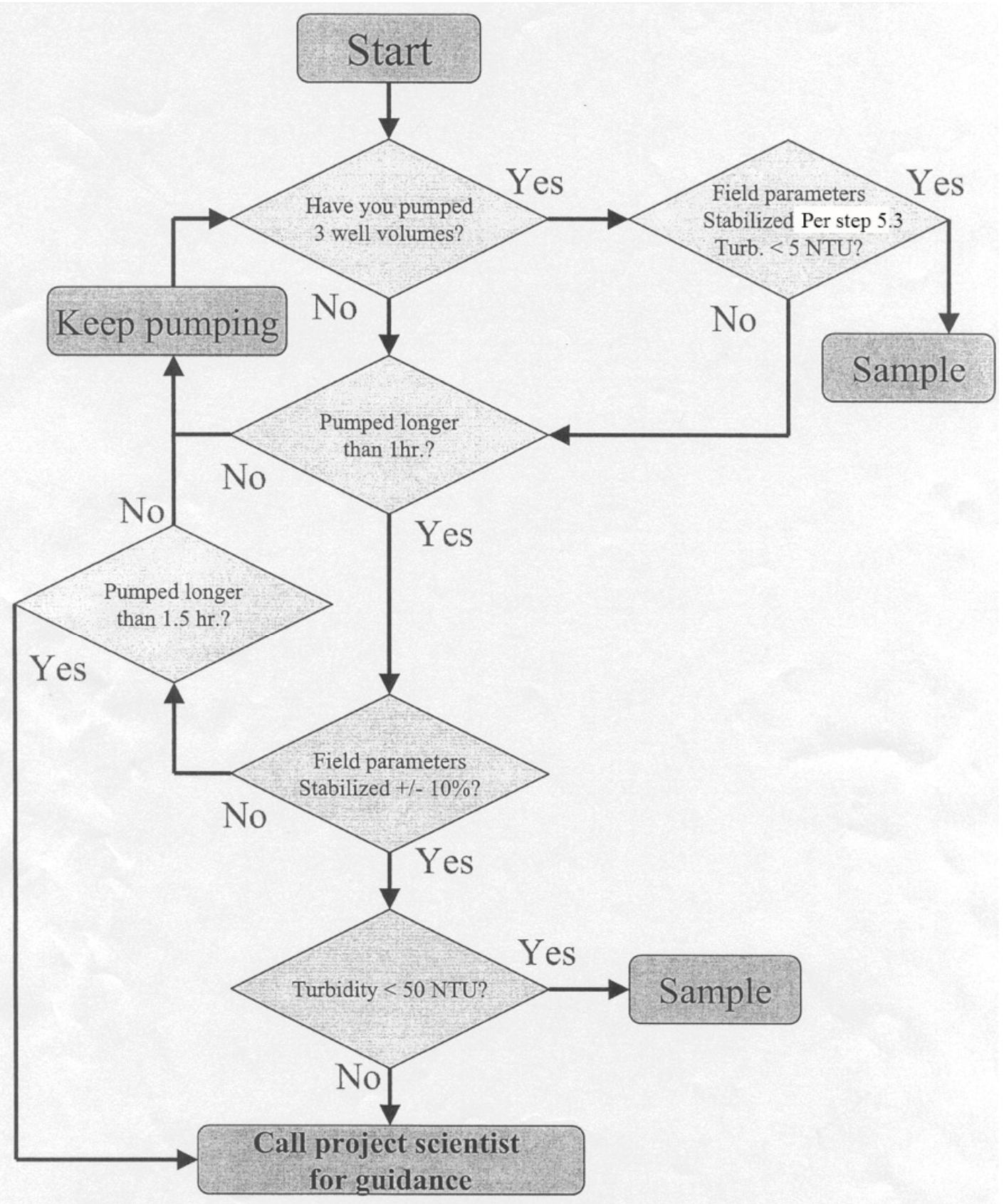


Appendix B

Groundwater Well Construction Documentation 



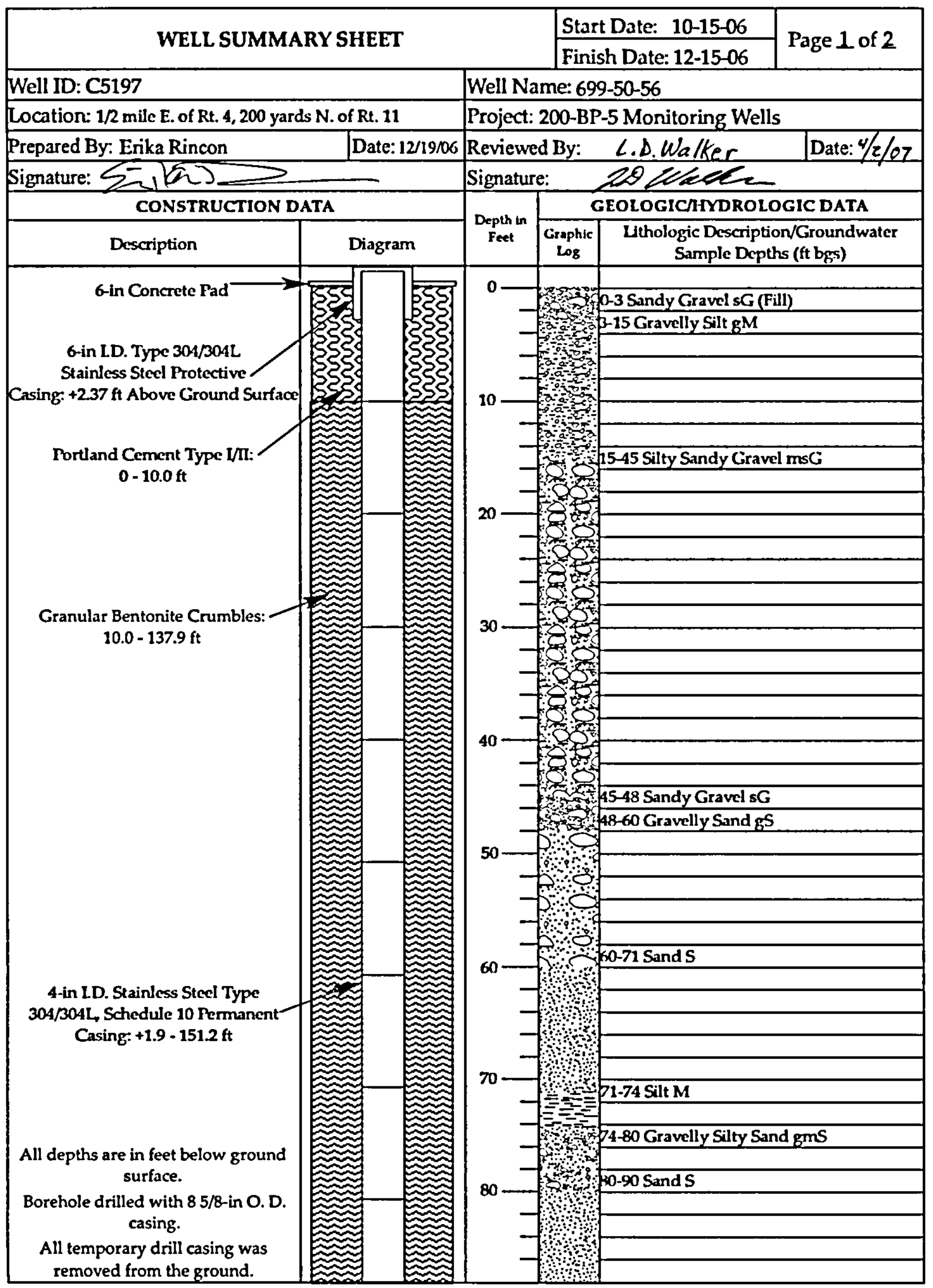




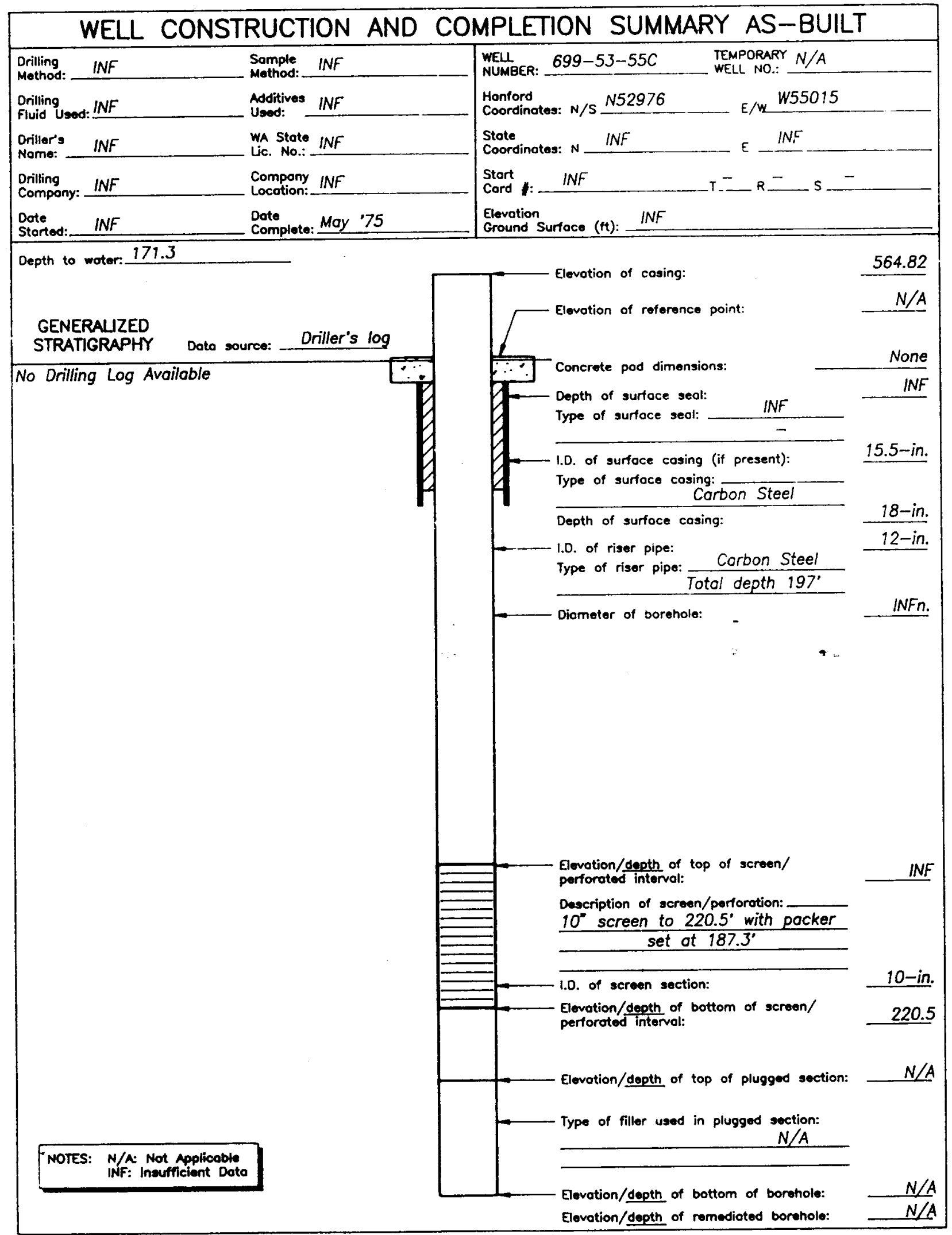

$8837152 \backslash 65355 C$ 


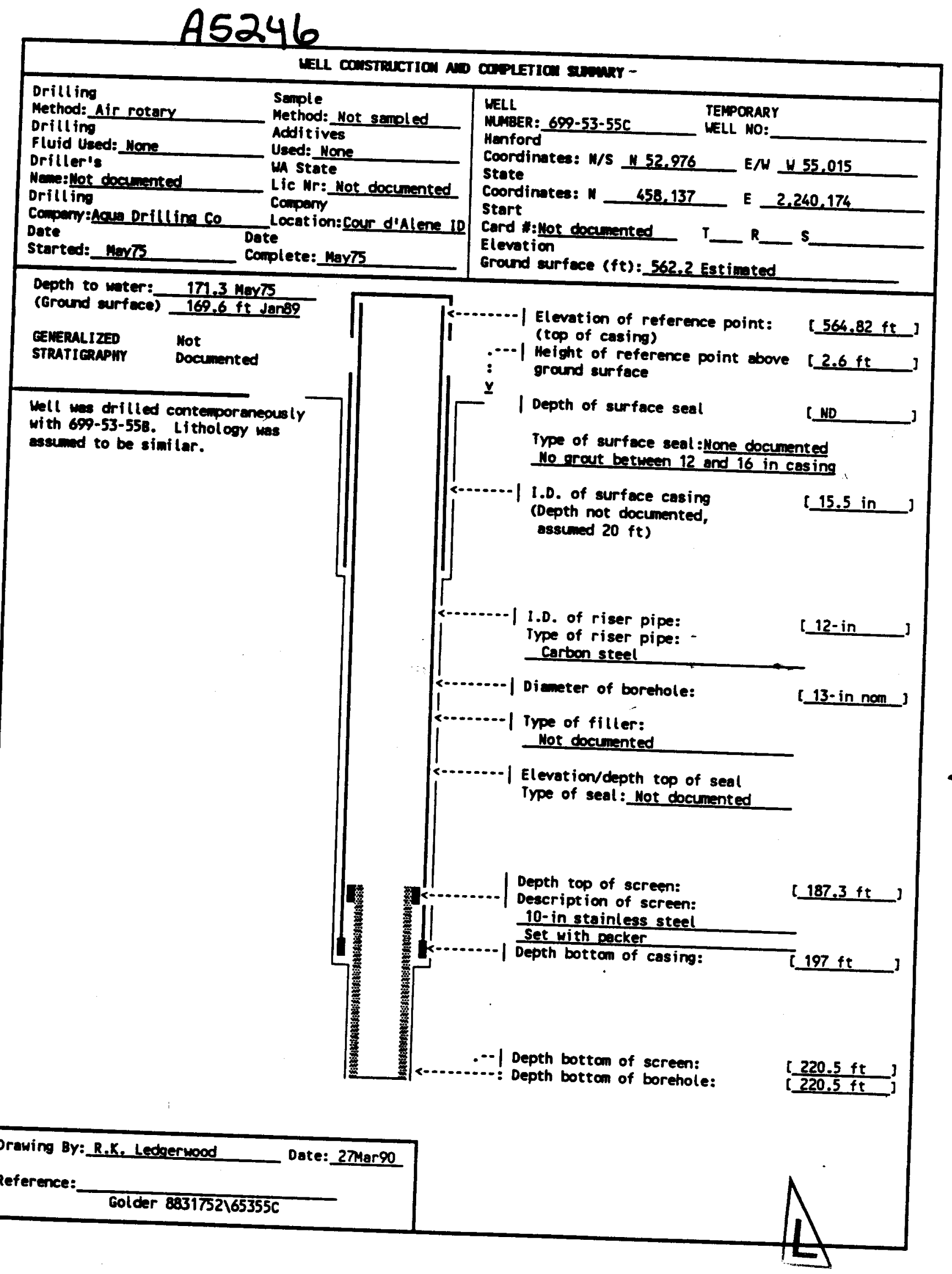




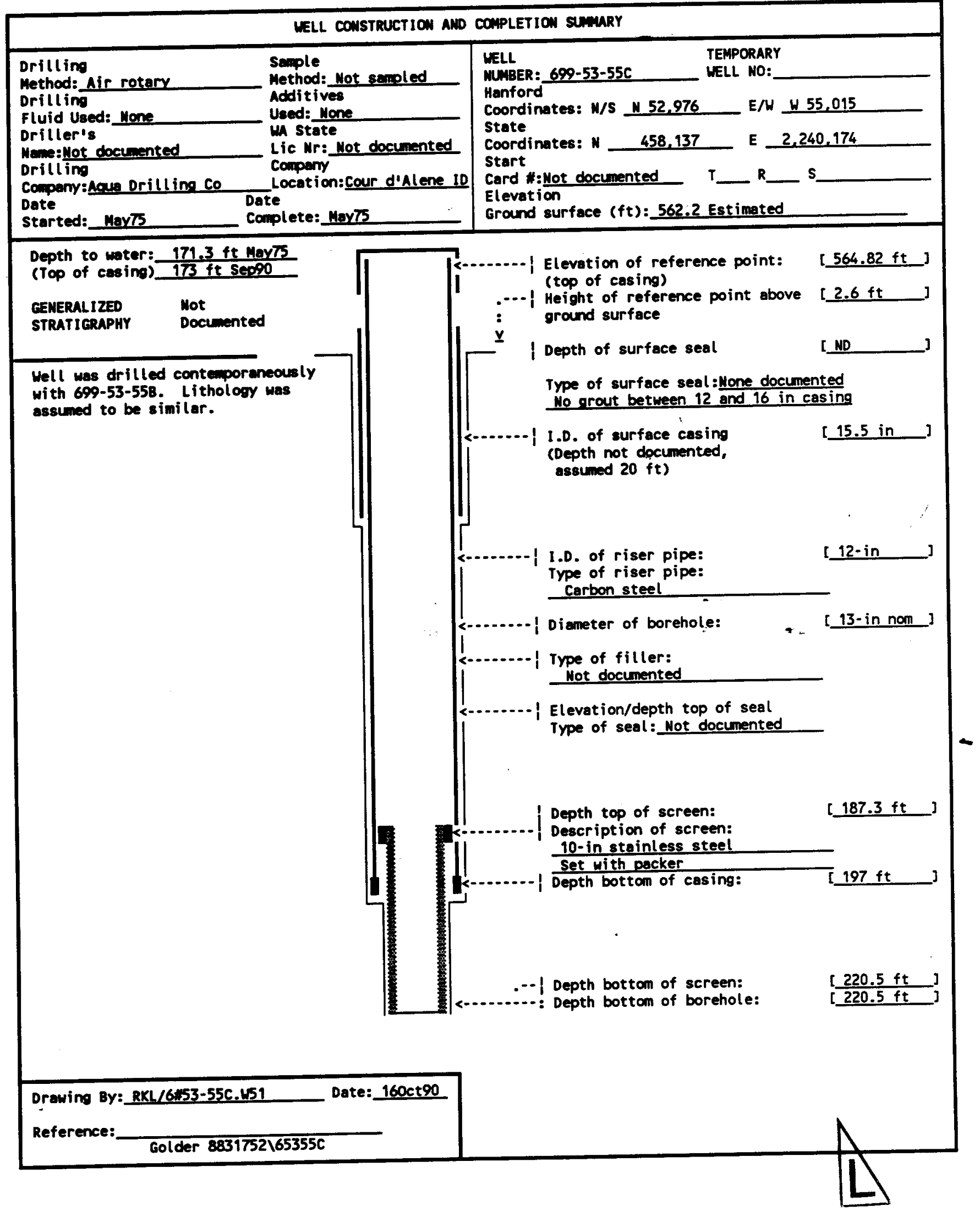


WELL CONSTRUCTION DATA FOR 200-BP1 WELLS, Monday November 12, 1990. 2:31 pm

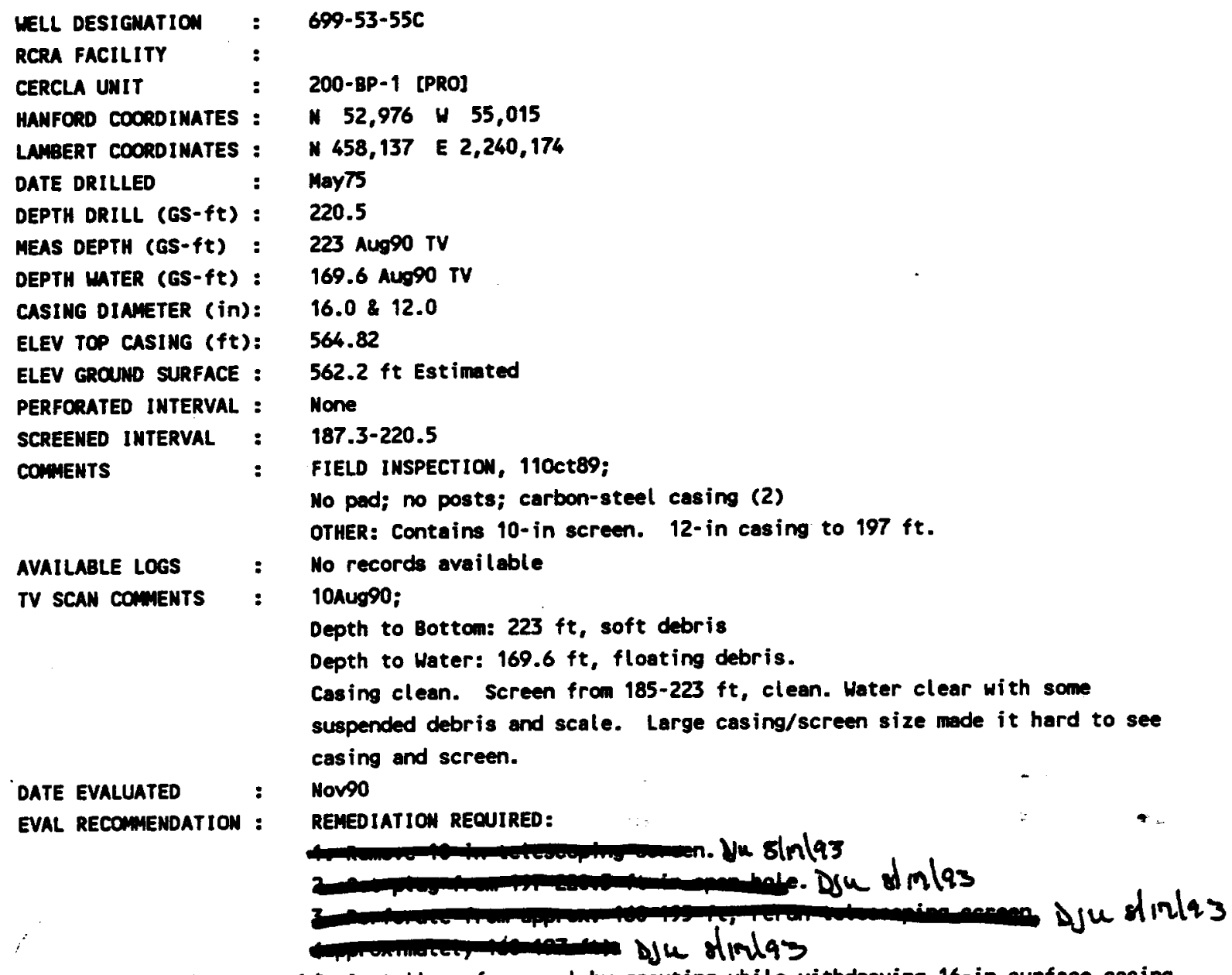

Djuyla/f. Install surface seal by grouting while withdrawing 16 -in surface casing. bj unls 25 Install protective posts and concrete pad per WAC 173-160-510 and field
conditions.

Sou fulat? $\boldsymbol{\mu}$. Survey to water level measurenent standards.

LISTED USE PUAP TYPE MAINTENAMCE sepations aty w/l

: Hydrostar, intake at $208.72 \mathrm{ft}$.

: 03May90; Renoved debris, scrubbed casing and screen and bailed debris. 12-13Jung0; Developed well with pump to <5 NTU. 23Aug90; Installed pump and new cap. 


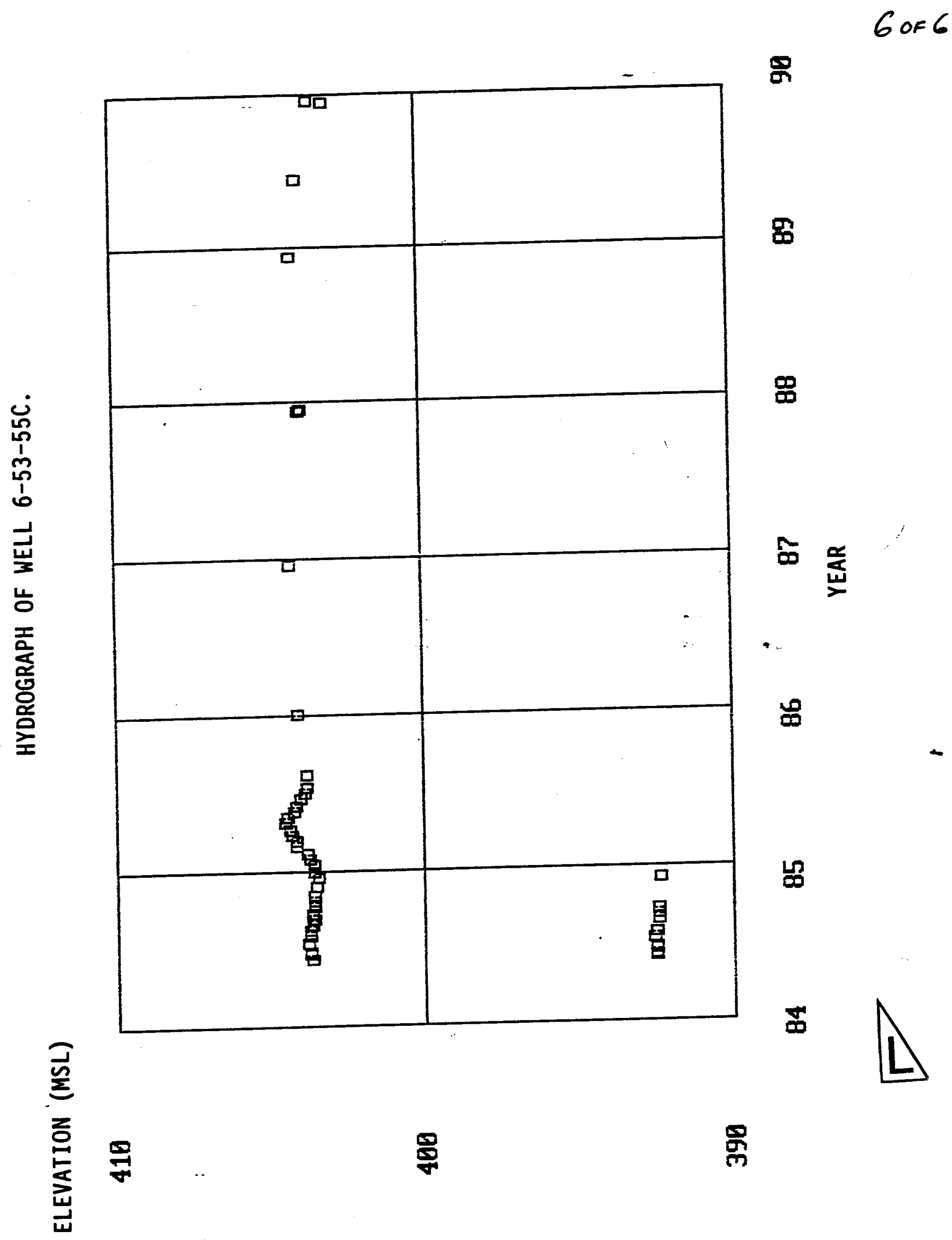




\section{WELL CONSTRUCTION SUMMARY REPORT}

Start Date: $3 / 12 / 08$

Finish Date: $4 / 23 / 08$

Page 1 of 1

Well ID: $C 5857$ Well Name: $299-E 33-342$

Project: $B P-5-0$ U Remedial Investigation

Driling Company: Bluestar

Driller: Justin Ereland License \#: 2843 TEMPORARY CASING AND DRILL DEPTH

\begin{tabular}{|c|c|c|}
\hline "Size/Grade/Lbs. Per Ft. & Interval & Shoe O.D.I.D. \\
\hline $113 / 4 "$ OD Carbon Steel & $0-98.56^{\prime}$ & $12^{1 / 2}+/ 105 / 8^{\prime}$ \\
\hline $95 / 8^{\prime \prime}$ on & $0-245.5$ & $10^{\prime \prime} / 9^{3 / 4 n}$ \\
\hline All threaded & $\overline{-}^{-}-$ & \\
\hline & $\mathrm{S}^{-}$ & \\
\hline & $-{ }^{-} \rightarrow$ & \\
\hline
\end{tabular}

"Indlcate Wolded (W) - Flush Jolnt (FJ) Coupled (C) \& Thread Design
Approximate Location: $N$ of BY Tank Farm Other Companies: Freestone Envivonmental Geologist(s):

Laurel Stration, Stere Airhart, Pat Cabbage DRILLING METHOD HOLE DIAMETER (in.)/INTERVAL (ft)

Auger: $f$ Dlameter $11^{9 / 4^{\prime \prime}}$ From 0 to $98.56^{\prime}$

Cable Tool: $x \quad$ Diameter $95 / 8^{\prime \prime}$ From $98.56^{\prime}$ to $245.5^{\circ}$

Alr Rotary:

Diameter From

Diameter _ From _ to

Diameter_Erem_to to

Dianeter $\_$From

Drilling Fluid: Water

Total Amt. Of Water Added During Drlling: 85 gallons Static Water Level: 236.14 Date: 4/22/89 GEOPHYSICAL LOGGING

Well Straightness Test Results: PASS

\begin{tabular}{|l|l|l|l|}
\hline Date & Sondes (type) & Interval & Date \\
\hline
\end{tabular}

\begin{tabular}{|c|c|c|c|c|c|}
\hline NEUTRON MOISTURE/ & $0-98$ & $3 / 21 / 08$ & $m$ & - & 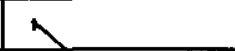 \\
\hline SPECTRAL GAMMA & $98-245.5$ & $4 / 15-4 / 16 / 08$ & & 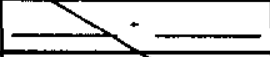 & \\
\hline 4 & 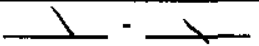 & $>$ & - & -1 & \\
\hline
\end{tabular}

\begin{tabular}{|c|c|c|c|c|}
\hline \multicolumn{5}{|c|}{ COMPLETED WELL } \\
\hline S|zo/Wh/Material & Depth & Thread & $\begin{array}{l}\text { slot } \\
\text { Slze }\end{array}$ & Type \\
\hline $4 " 10304 / 3$ oul scheder 10 & $+2.58 \cdot 244.6$ & $x$ & & Portland cument w/ hentonite \\
\hline Stainless steed & $\mathrm{L}^{\circ}$ & & & Granular bentonite \\
\hline $4^{\prime \prime} \quad 11$ Sero & $232.6-242.6$ & $x$ & 20 & bentonite pellets \\
\hline & $\square^{-}$ & & & Colorndo siliea sand \\
\hline Sump & $242.6-244.6$ & $y$ & & 7 \\
\hline
\end{tabular}

OTHER ACTIVITIES

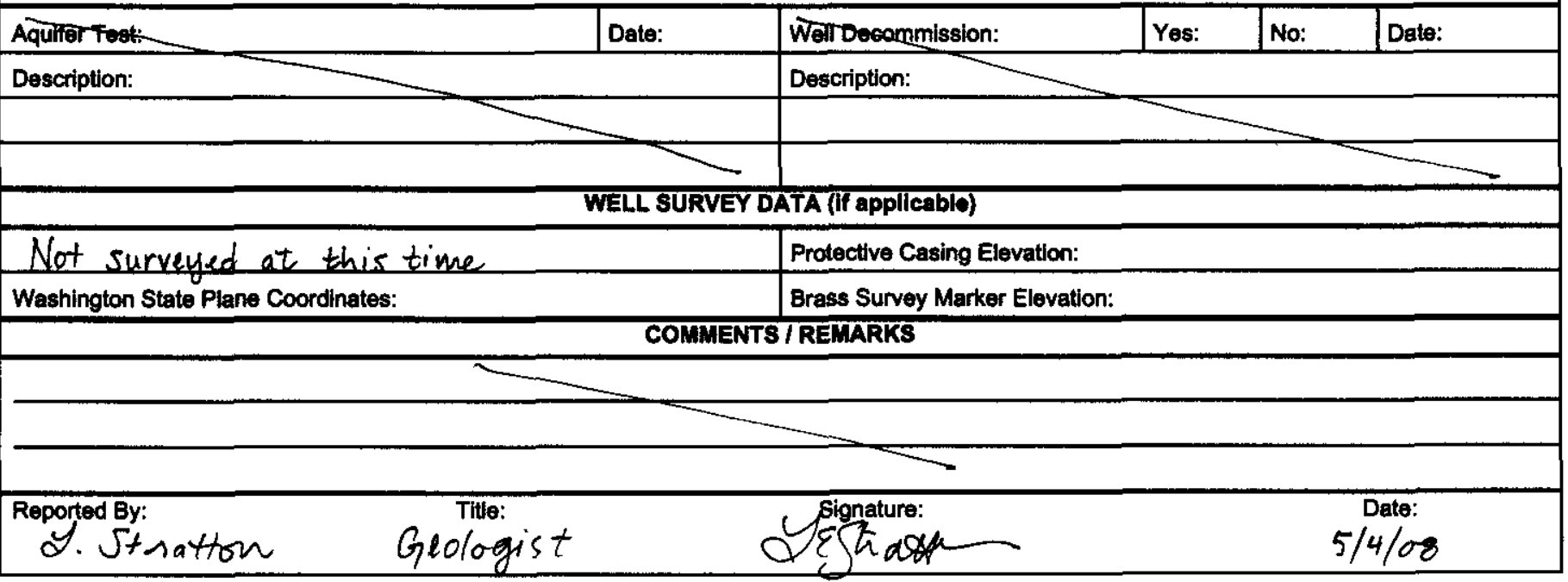




\section{WELL SUMMARY SHEET}

\section{Well ID: C5858}

Location: N of B Tank Farm

Prepared By: Laurel Stratton

Signature: $Q$ Segh CONSTRUCTION DATA

\begin{tabular}{|c} 
Description \\
\hline 6-in Concrete Pad \\
6-in I.D. Type 304/304L \\
Stainless Steel Protective \\
Casing: $\pm 5.27 \mathrm{ft}$ above ground su \\
Z.39
\end{tabular}

Portland Cement Type I/II: 0 - $9.8 \mathrm{ft}$ bgs

Granular Bentonite Crumbles: $9.8-233.2 \mathrm{ft}$ bgs

4-in I.D. Stainless Steel Type 304/304L, Schedule 10 Permanent

Casing: $5.249 .9 \mathrm{ft}$ bgs $1.39^{\prime}$
$464 / 6 y$

All depths are in feet below ground surface.

Borehole drilled with:

$131 / 2$ " threaded casing: $0.0-60.00 \mathrm{ft}$ bgs

$113 / 4^{\prime \prime}$ threaded casing$60.00-238.30 \mathrm{ft}$ bgs

95/8" threaded casing: 238.30-263.8 ft bgs

All temporary drill casing was removed from the ground. \begin{tabular}{|l|l|}
\hline Start Date: $1 / 15 / 08$ & Page $\underline{1}$ of $\underline{3}$ \\
\hline Finish Date: $3 / 10 / 08$ &
\end{tabular}

Well Name: 299-E33-343

Project: 200-BP-5 RI/FS

Date:3/31/08 Reviewed By: L.S.Walker Date:6/5/08 Signature:

GEOLOGIC/HYDROLOGIC DATA

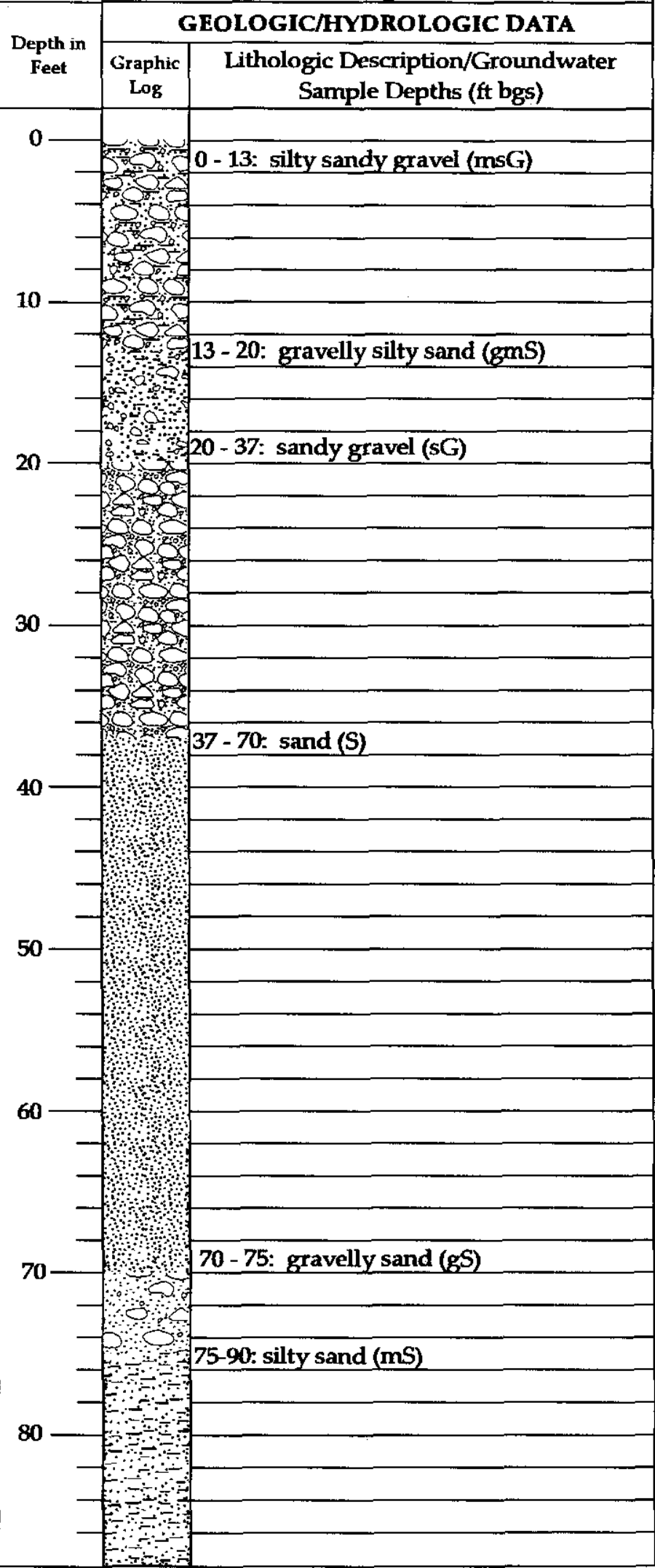


WELL SUMMARY SHEET

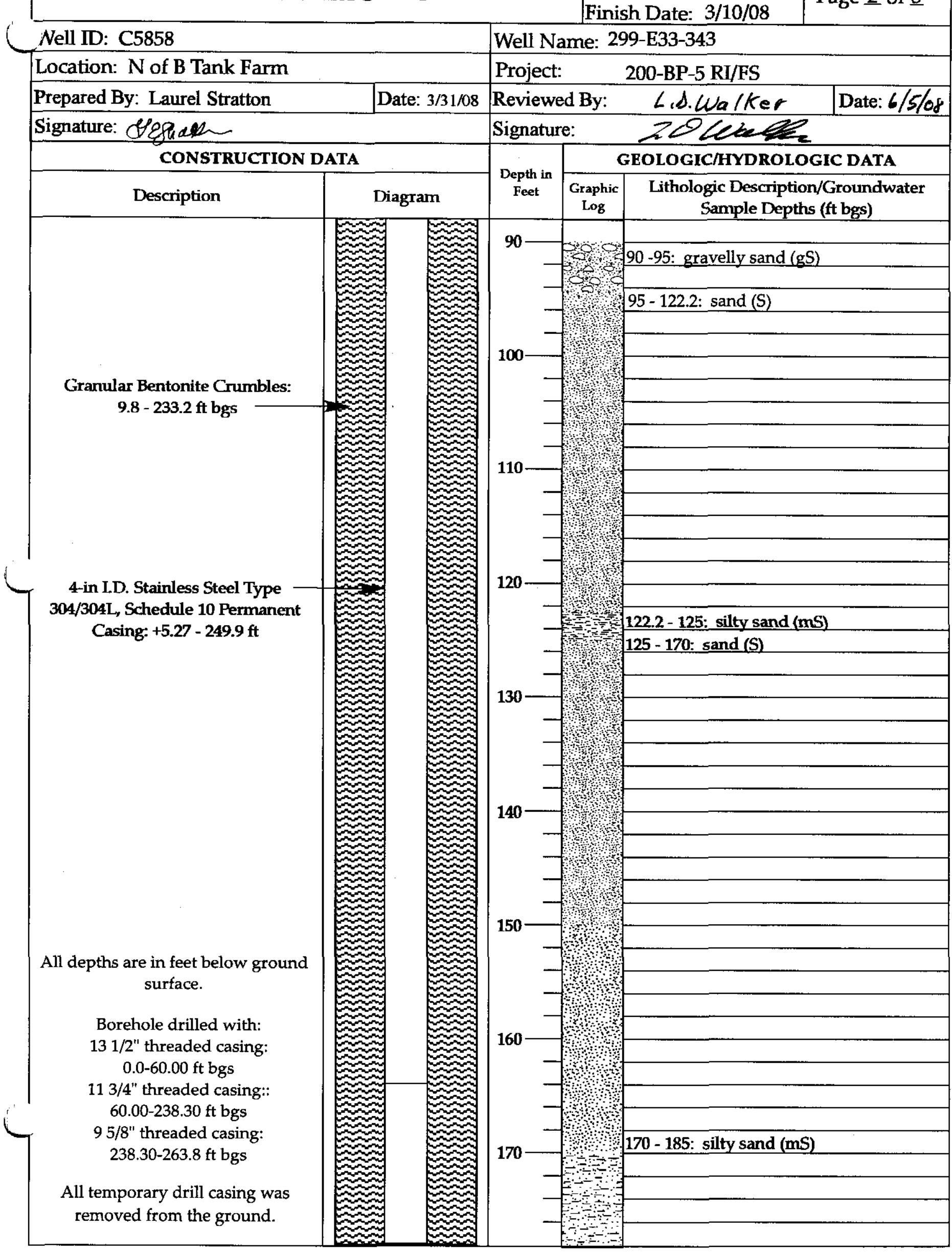


WELL SUMMARY SHEET

Well ID: C5858

Location: N of B Tank Farm

Prepared By: Laurel Stratton

Signature: पै\&grasan

\begin{tabular}{|c|c|}
\hline \multicolumn{2}{|c|}{ CONSTRUCTION DATA } \\
\hline Description
\end{tabular}

Granular Bentonite Crumbles:

9.8 - $233.2 \mathrm{ft}$ bgs

4-in I.D. Stainless Steel Type

304/304L, Schedule 10 Permanent Casing: $+5.27-249.9 \mathrm{ft}$

3/8-in Bentonite Pellets:

233.2 - $241.0 \mathrm{ft}$ bgs

Primary Filter pack

10-20 Mesh Colorado Silica Sand:

$241.0-263.4 \mathrm{ft}$ bgs

Static Water Level:

$252.14 \mathrm{ft}$ bgs $(3 / 4 / 08)$

4-in I.D. Stainless Steel Type 304/304L, Slot 20 (0.20-in) Screen:

249.9 - $259.9 \mathrm{ft}$ bgs

4-in I.D. Stainless Steel Type 304/304L Sump: $259.9-262.9 \mathrm{ft}$ bgs
Start Date: $1 / 15 / 08$

Finish Date: 3/10/08

Page 3 of 3

Well Name: 299-E33-343

\begin{tabular}{ll|l} 
Project: 200-BP-5 RI/FS & \\
Reviewed By: L, L.Wa/ker & Date: $6 / 7 / 08$
\end{tabular}

Signature: rofekes

Depth in $\quad$ GEOLOGIC/HYDROLOGIC DATA

\begin{tabular}{c|c|c|c} 
Feet & Graphic & Lithologic Description/Groundwater
\end{tabular}

\begin{tabular}{l|l|l} 
& Log & \multicolumn{2}{c}{ Sample Depths (ft bgs) } \\
\hline 180 & & $170^{\prime}$
\end{tabular}

180 185: silty sand (mS)

185 - 195: slightly silty sand $(\mathrm{mS})$

190

$+3$

\begin{tabular}{lll}
\hline $195-200:$ sand $(\mathrm{S})$ \\
\hline
\end{tabular}

200

(1)

210

215.5 - 225: abrupt contact with compact




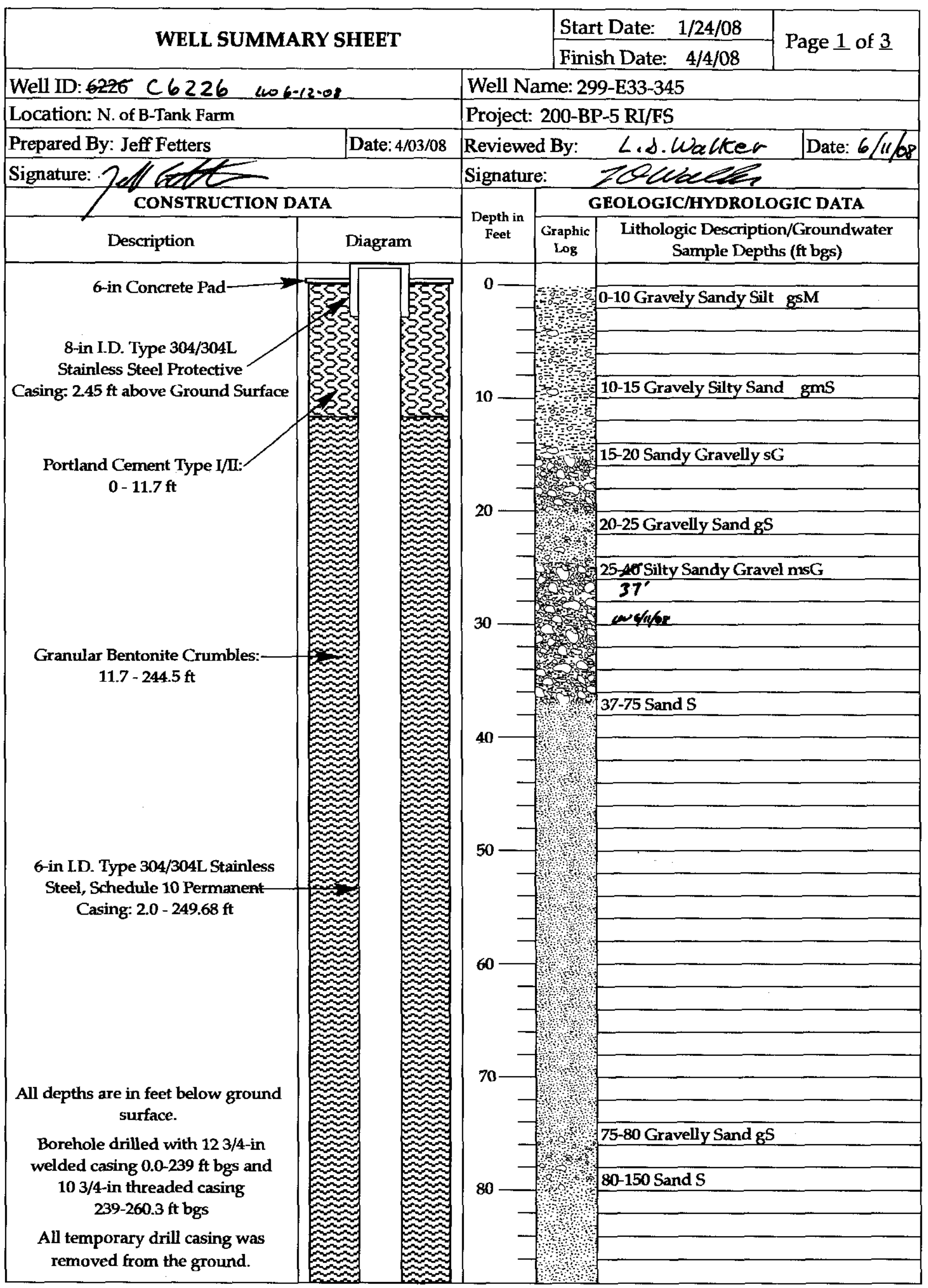


WELL SUMMARY SHEET

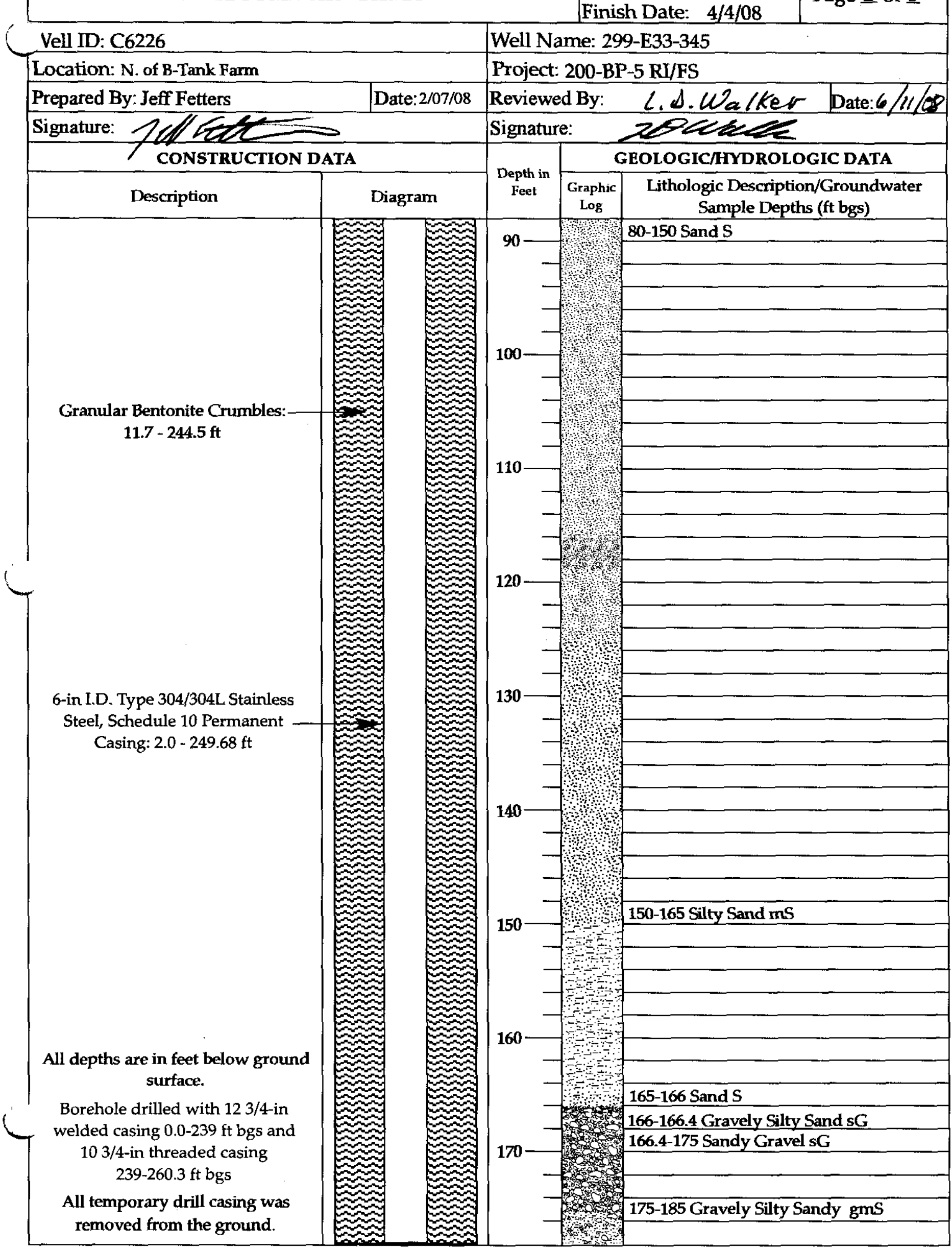


WELL SUMMARY SHEET

Well ID: C6226

Location: N. of B-Tank Farm

Prepared By: Jeff Fetters

Signature:

Signature: ZCl/EEQ
CONSTRUCTION DATA

All depths are in feet below ground surface.

Borehole drilled with 12 3/4-in welded casing 0.0-239 $\mathrm{ft}$ bgs and

$103 / 4$-in threaded casing 239-260.3 ft bgs

All temporary drill casing was removed from the ground.

Granular Bentonite Crumbles: $11.7-244.5 \mathrm{ft}$

6-in I.D. Type 304/304L Stainless Steel, Schedule 10 Permanent Casing: $2.0-249.68 \mathrm{ft}$

Diagram
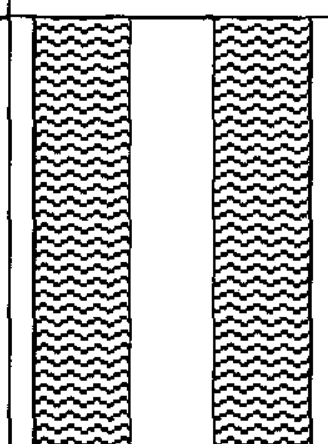

\begin{tabular}{|l|l|}
\hline Start Date: $1 / 24 / 08$ & Page 3 of 3 \\
\hline Finish Date: $4 / 4 / 08$ &
\end{tabular}

Well Name: 299-E33-345

Project: 200-BP-5 RI/FS

Reviewed By: L.J. Wa/ker Date:6/11/08

Signature: $>$

\begin{tabular}{|c|c|c|}
\hline \multirow{2}{*}{$\begin{array}{l}\text { Depth in } \\
\text { Feet }\end{array}$} & \multicolumn{2}{|c|}{ GEOLOGIC/HYDROLOGIC DATA } \\
\hline & $\begin{array}{l}\text { Graphic } \\
\text { Log }\end{array}$ & Lithologic Description/Ground \\
\hline
\end{tabular}

180

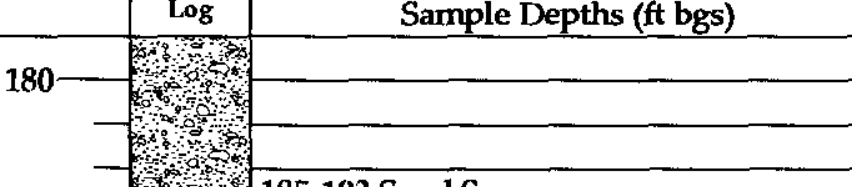

185-193 Sand S

190

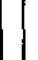

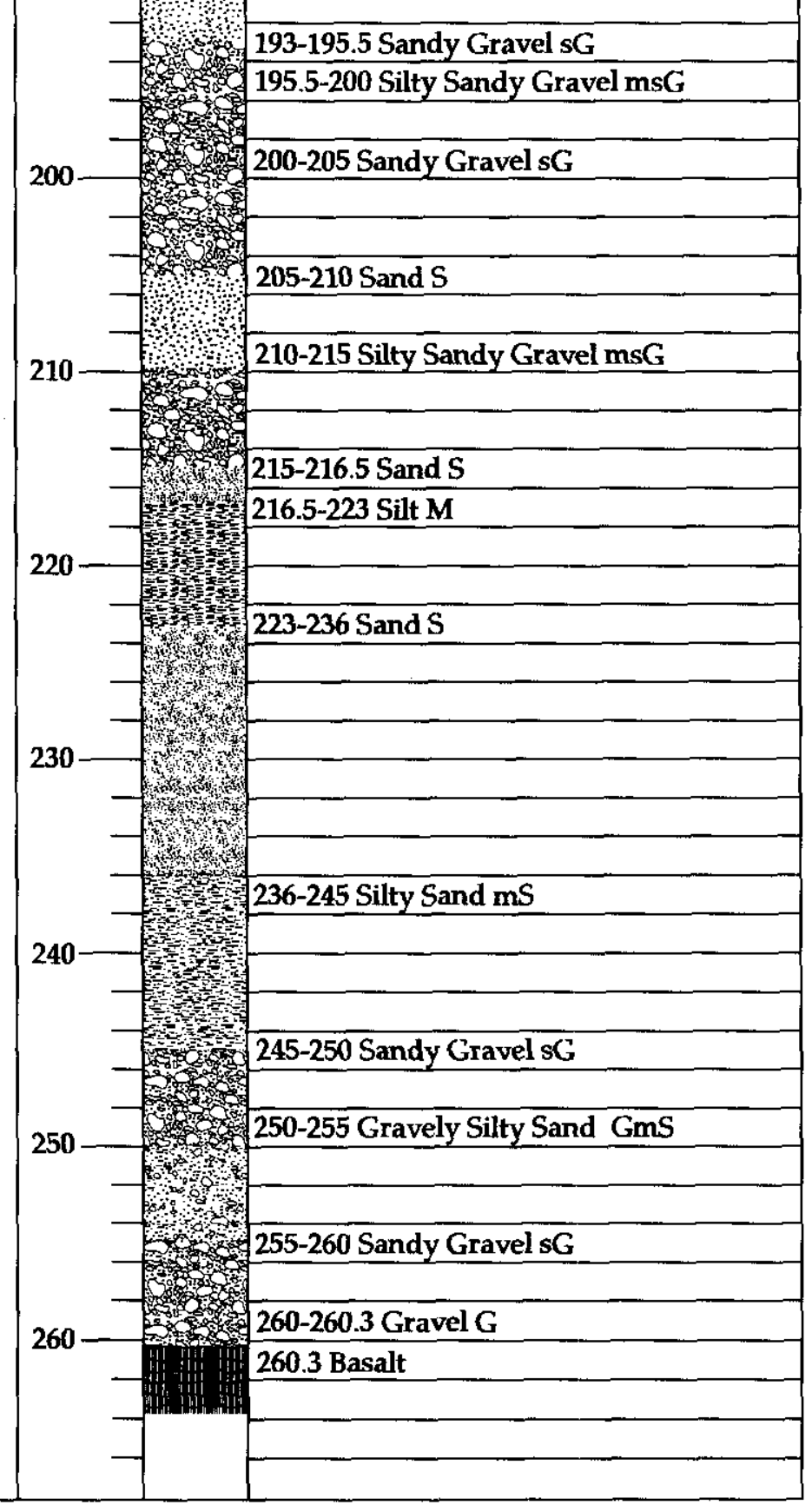


WELL SUMMARY SHEET

0540323

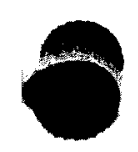

Well ID: $C_{3392}$

Location: SE Corner of $241-B X$ Tank Farm

\begin{tabular}{ll|l} 
Prepared By: Jess Hocking & Date:
\end{tabular}

Signature: for Hocking

\begin{tabular}{|l|l|}
\hline Description & Diagram \\
\hline
\end{tabular}

6"- dia. protective casing set above stainless casing.

4"ID SS 304L casing:
$+2.00 \longrightarrow 259.4^{\prime}$
Portland cement grout:
$0 \longrightarrow 10.4$ "

Bentonite crumbles:

$\frac{10.4^{\prime} \longrightarrow 244.35^{\prime}}{1 / 4^{\prime \prime}+3 / 8 " \text { Bentonite pellets: }}$

$244.35^{\prime} \rightarrow 249.7^{\prime}$

4"ID SS $304 L \quad 0.020$ in. Slot

cont. Wire-wrap well sereen:

\begin{tabular}{|l|}
$259.4^{\prime} \longrightarrow 279.3^{\prime}$ \\
$10-20$ mesh silica sand \\
$249.7^{\prime} \longrightarrow 283.1^{\prime}$
\end{tabular}

4"ID \$5304L Tailpipe:

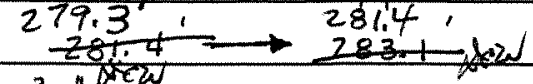

$3 / 8$ " Bentonite Pellets (coated):

$283.1^{\prime} \longrightarrow 285.6$ in $^{\prime}$ dew

All temp. casing removed:

All depths are in feet below

ground surface.

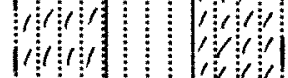
ind $1: \infty$
Well Name: $299-E 33-3.39$

Project: CYOI RCRA Drilling

Reviewed By: DCweekes $\quad$ Date: $q / 19 / 01$

Signature: Creeket

\begin{tabular}{|c|c|c|}
\hline \multirow{2}{*}{$\begin{array}{c}\text { Depth in } \\
\text { Feet }\end{array}$} & \multicolumn{2}{|c|}{ GEOLOGIC/HYDROLOGIC DATA } \\
\hline & $\begin{array}{c}\text { Graphic } \\
\text { Log }\end{array}$ & Lithologic Description \\
\hline
\end{tabular}

$0-\Delta \Delta \Delta \Delta 0^{\prime}-6^{\prime}$ Backfill material - $00: 0: 10^{\prime}$ silty sandy Gravel (mot)

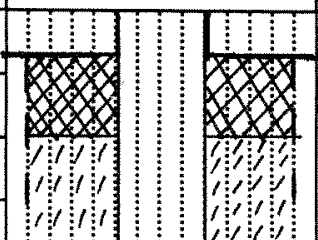

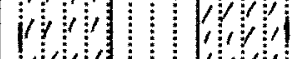
1:11 $1, y$

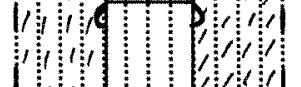

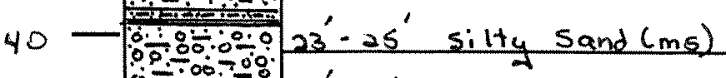
-0.0015 slightly silty Sandy Gravel $18.5^{\prime}-20^{\prime}$ silt lens F. $-0.0 .0 \% 20^{\circ}-23^{\prime}$ sand (5) - Pa 28 silt lens

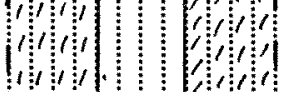
$111 ! 1=1$

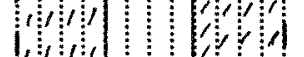

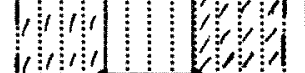
$30^{\prime}-34^{\prime}$ silty Sand Gravel (msG) $34^{\circ}-37^{\prime}$ silty sand (ms) $37^{\prime}-27.5^{\prime}$ (siltiens) M $375^{\prime}-55$ silly sandy gravel (mst) $55^{\prime}-56^{\circ}$ sandy Gravel (5G) $56^{\prime}-223^{\prime}$ sand (5) $223^{\prime}-225^{\prime}$ gravelly Sand (q5) $225^{\prime}-235^{\prime}$ sandy Gravel (sti) $235^{\prime}-250^{\prime}$ si silty sandy Gravel (ros)

120

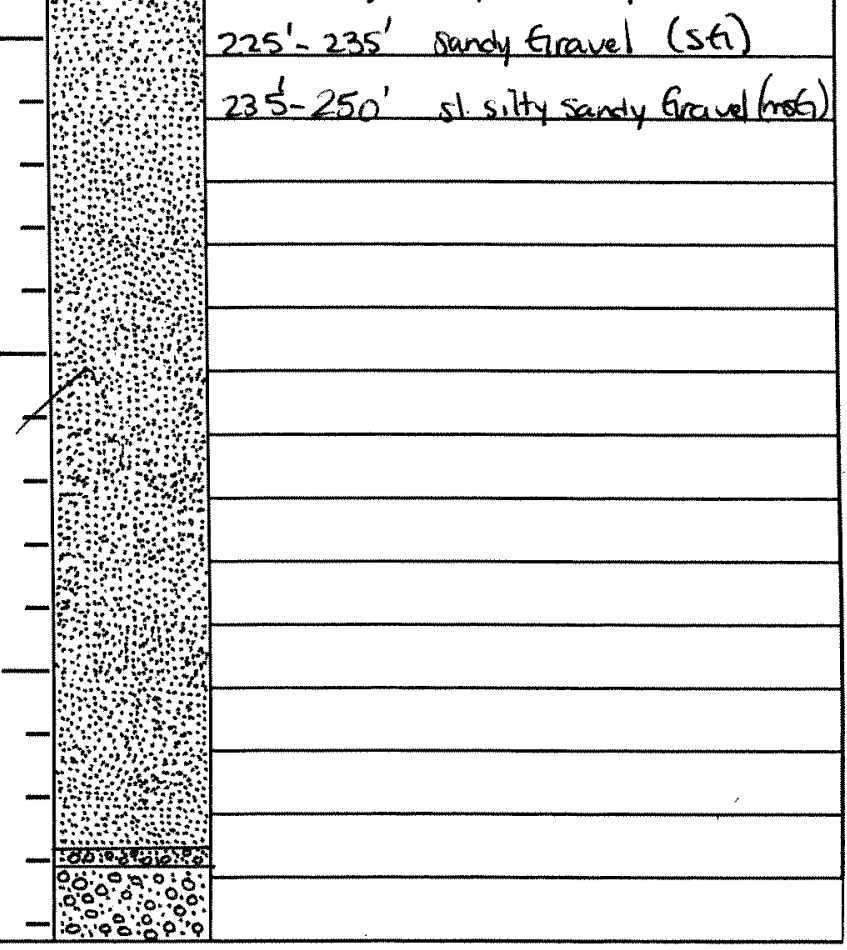


WELL SUMMARY SHEET

\begin{tabular}{l} 
Page 2 of 2 \\
\hline Date: $7 / 18 / 01$
\end{tabular}

Well ID: C3392

Well Name: $\quad 299-E 33-339$

Location: SE Corner of 241-Bx Tank Farm

Project: RCRA FY-OI

Prepared By: Jess Hocking

Signature: fow Poekeng

Date: $8 / 17 / 01$

CONSTRUCTION DATA

Description

Reviewed By: DCWeekes

Signature: A'cleeber

Date: $9 / 19 / 01$

Depth in $\quad$ GEOLOGIC/HYDROLOGIC DATA

Feet $\begin{gathered}\begin{array}{c}\text { Graphic } \\ \text { Log }\end{array} \\ \text { Lithologic Description }\end{gathered}$

$240-\frac{1}{2}-250^{\prime}$ Gravel $(G)$

- $252-253.5^{\prime}$ Silt $(m)$

- $\quad 0 \%$ sisity sundy truvel (mst)

$=-164^{\prime}-260^{\prime}$ fravel (G)

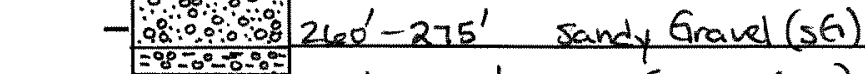

280 - $275^{\prime}-279^{\prime}$ silty Gravel (mt)

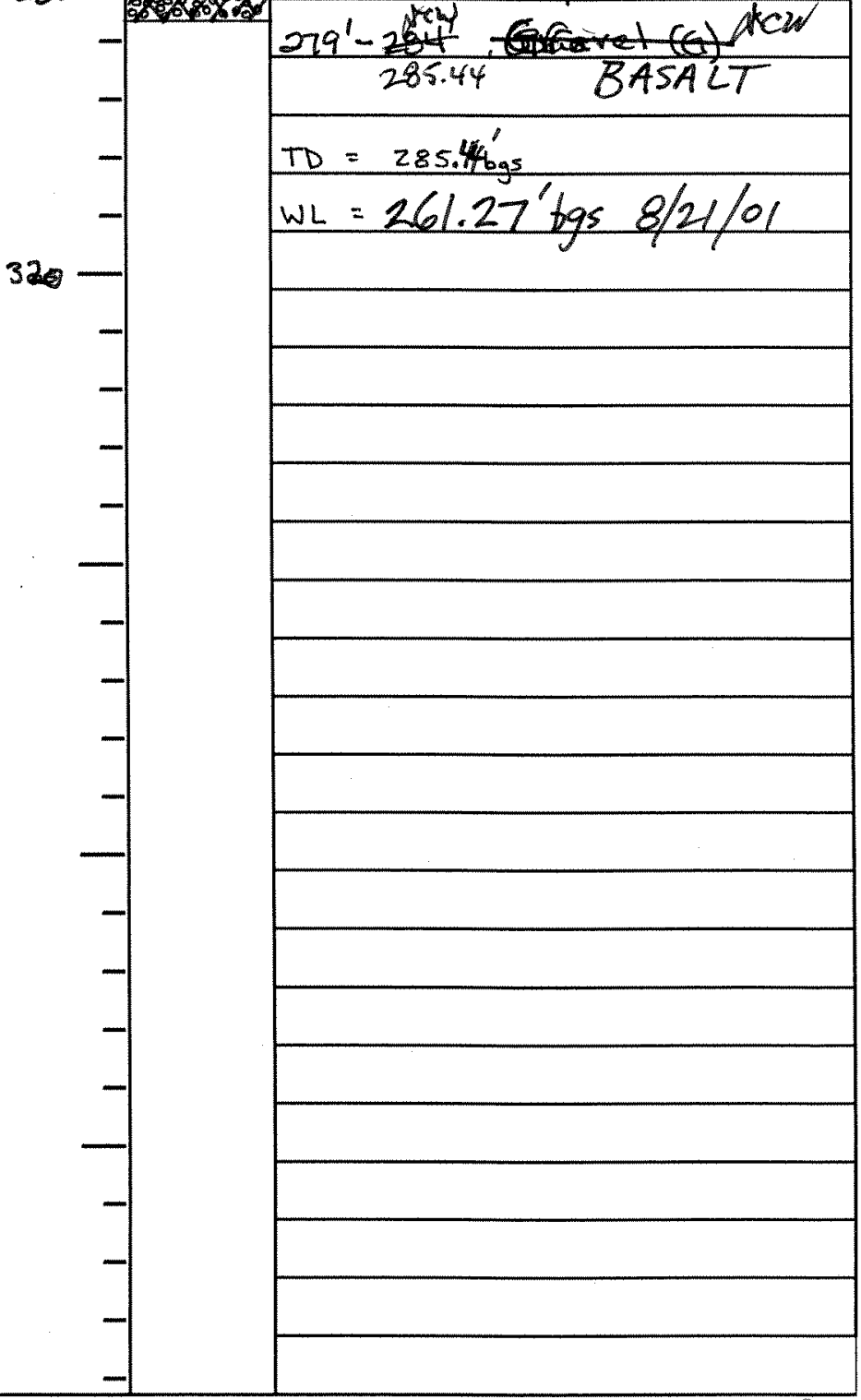


Well ID $\quad$ C4261 \begin{tabular}{|l|l|l|l|l|}
\hline Prepared By Charleme martinez & Date.08/1ilat & Reviewed By L.D.Walker & Date. 8/25/04 \\
\hline
\end{tabular} Signature. charlen Thartive

\begin{tabular}{c} 
CONSTRUCTION DAt \\
Description \\
\hline 10.20 MESH SILICA SAND \\
$288.4^{\prime} \rightarrow 258.6^{\prime}$ \\
\hline $3 / 8^{\prime \prime}$ Sodium Bentonite Pellets \\
\hline $258.6^{\circ} \rightarrow 2537^{\circ}$ \\
\hline
\end{tabular}

Sodium Bentonite Crumbles $253.7^{\circ} \rightarrow 9.5^{\prime}$

Type I/II Portland Cement $9.5^{\prime} \rightarrow 0^{\prime}$

4" TP- 304/304t sch. 05s Riser $+1.99^{\prime} \rightarrow 263.5^{\prime}$

"1. 0.020 " LONT 4"TP-304/304L sch. 05s WherefeN $263.5^{\prime} \rightarrow 283.5^{\prime}$

$4 " T P-304 / 304 L$ sch $05 ;$ Sump $283.5^{\prime} \rightarrow 286.5^{\prime}$

6 "ID protective casing (ss 304, sch 5) set: $t 1.00^{\prime}$ above permament. All depths in feet below ground surface.

All temporany casing $\left(10^{\prime \prime}\right)$ nomoved from ground
Diagram

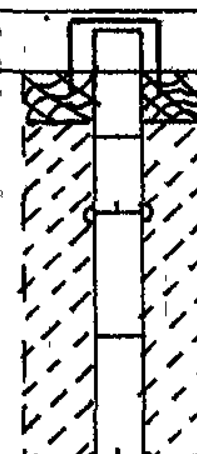

$r, x+2$

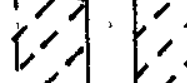

rist

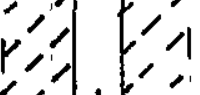

r.s-is

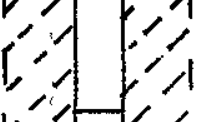

v's

v's

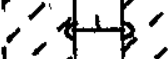

1

1,1

$1 \leq 1:\{=1$

c-did

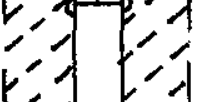

$r$
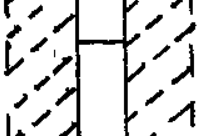

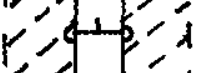

signature

\begin{tabular}{|c|c|c|}
\hline \multirow{2}{*}{$\begin{array}{l}\text { Depth in } \\
\text { Feet }\end{array}$} & \multicolumn{2}{|c|}{ GEOLOGIC/HYDROLOGIC DAT/ } \\
\hline & $\begin{array}{c}\text { Graphic } \\
\text { Log }\end{array}$ & Litholo \\
\hline
\end{tabular}

$0 \longrightarrow \frac{10}{0}$

$0-55^{\prime}$ slighty Silty Gravelly SAND (m)gs 5.5'-13'silty Sandy GRAVEL ( $m 5$ G)

$0: 0: 0.015$ :0: $16^{\prime}-17^{\prime}$ SAND (s) 17-45.5' Sandy

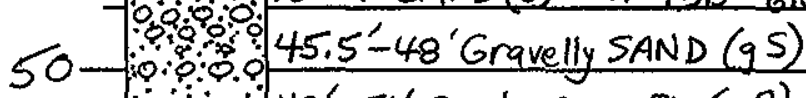
$\because \because 48^{\prime}-51^{\prime}$ Sandy GRAVEL (SG) $51^{\prime}-93^{\prime}$ SAND (S)

93'-98' slightly silty SAND (m)S $98^{\prime}-163^{\prime}$ SAND (s)

100

$-\because \because 9$

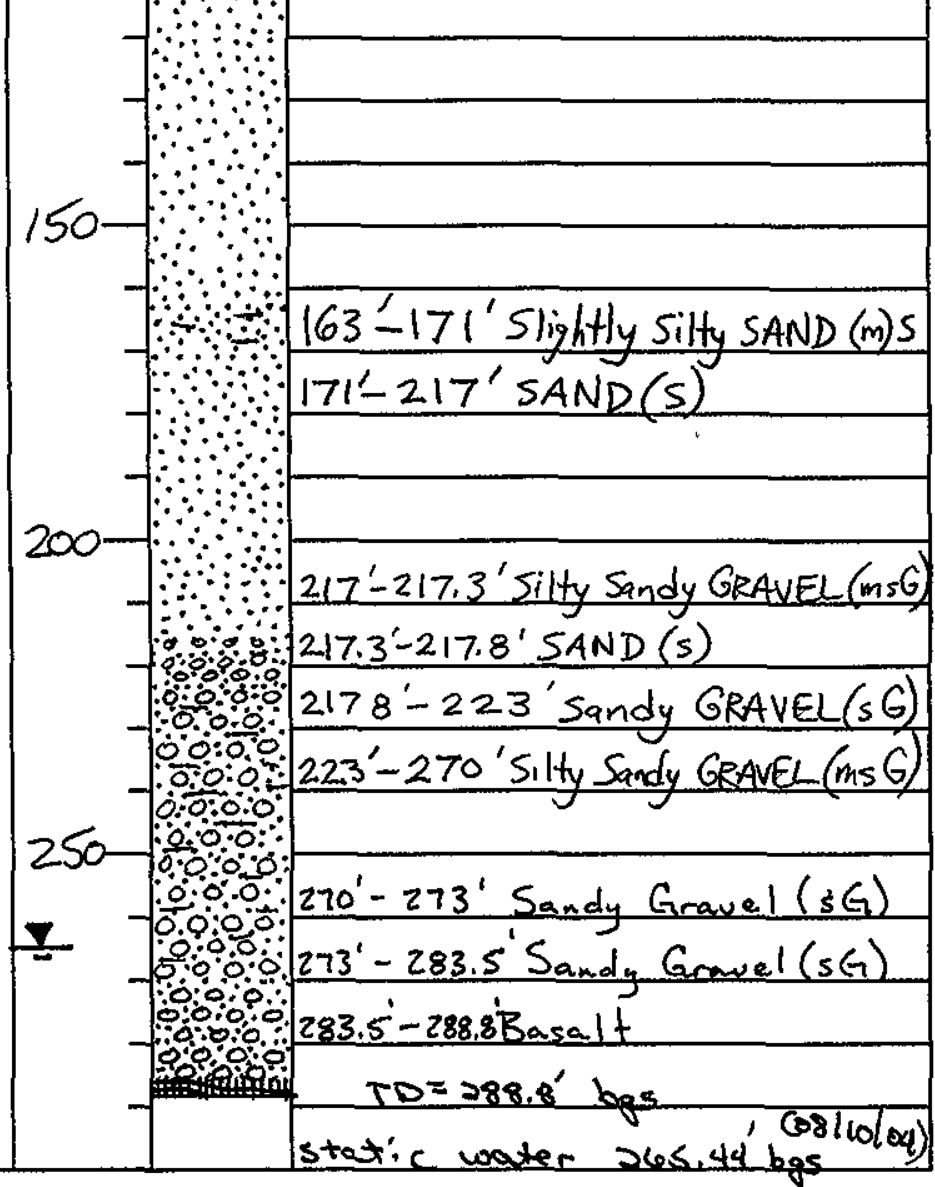

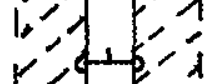

:0:0:13'-16' Gravelly SAND + Sandy GRAVEL 
Locsion 200E; APREOX. 1000 'E. OF THE BY CRIBS Proer CERCLA 20C-BP-1

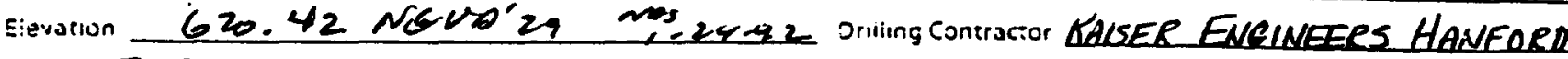

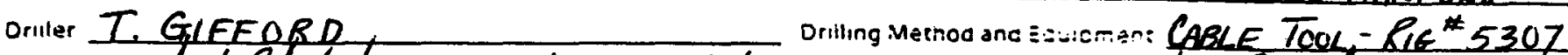

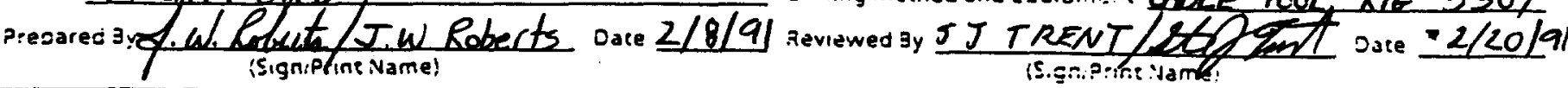

CONSTRUCTION DATA

$21.04 \mathrm{ft}$ stainless steel continuous wire wrap screen $(0.020$-in s6t) from 229.2 to $208.16^{\prime}$ ( 4 " ID). Stainless steel thread casing to above ground surface $8-12$ sand 229.3'-203.1' Bentonite pellets $203.1^{\prime}-199.6^{\prime}$ 8-20 Bentonite crumbles 199.6-20,0 Protland cement 20.0'-2.0'

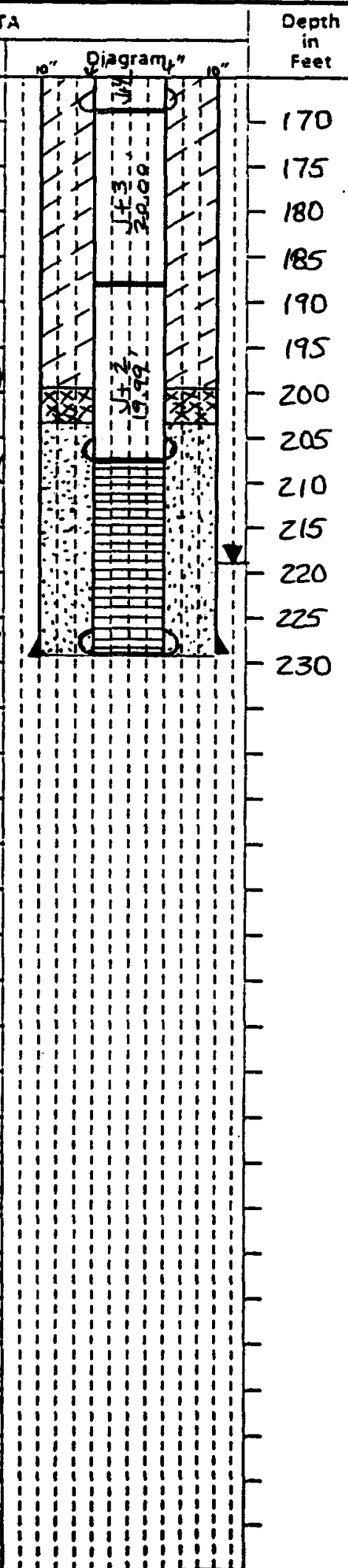

GEOLOGICHYDROLOGIC DATA

Graphic Log ! Lithologic Description

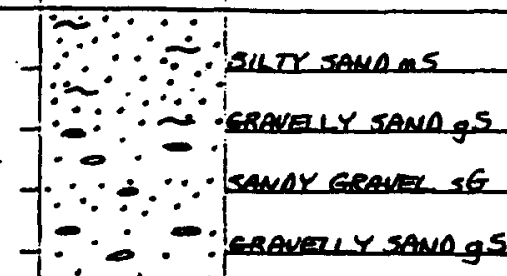

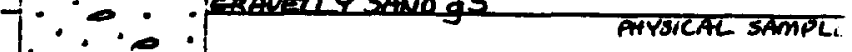

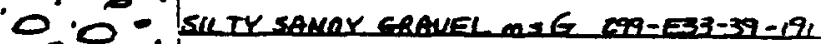
-0.0.0

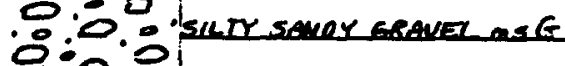

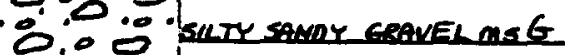

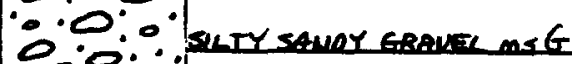

- 00

-0.0.0.5uty saver grava mat

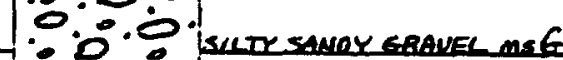

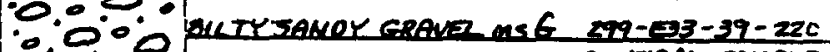
- -0.0 pHYSICAL SAmpLe

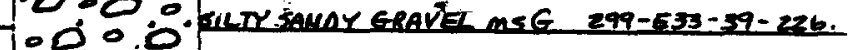
$\because \because \because \because \because$ sanes

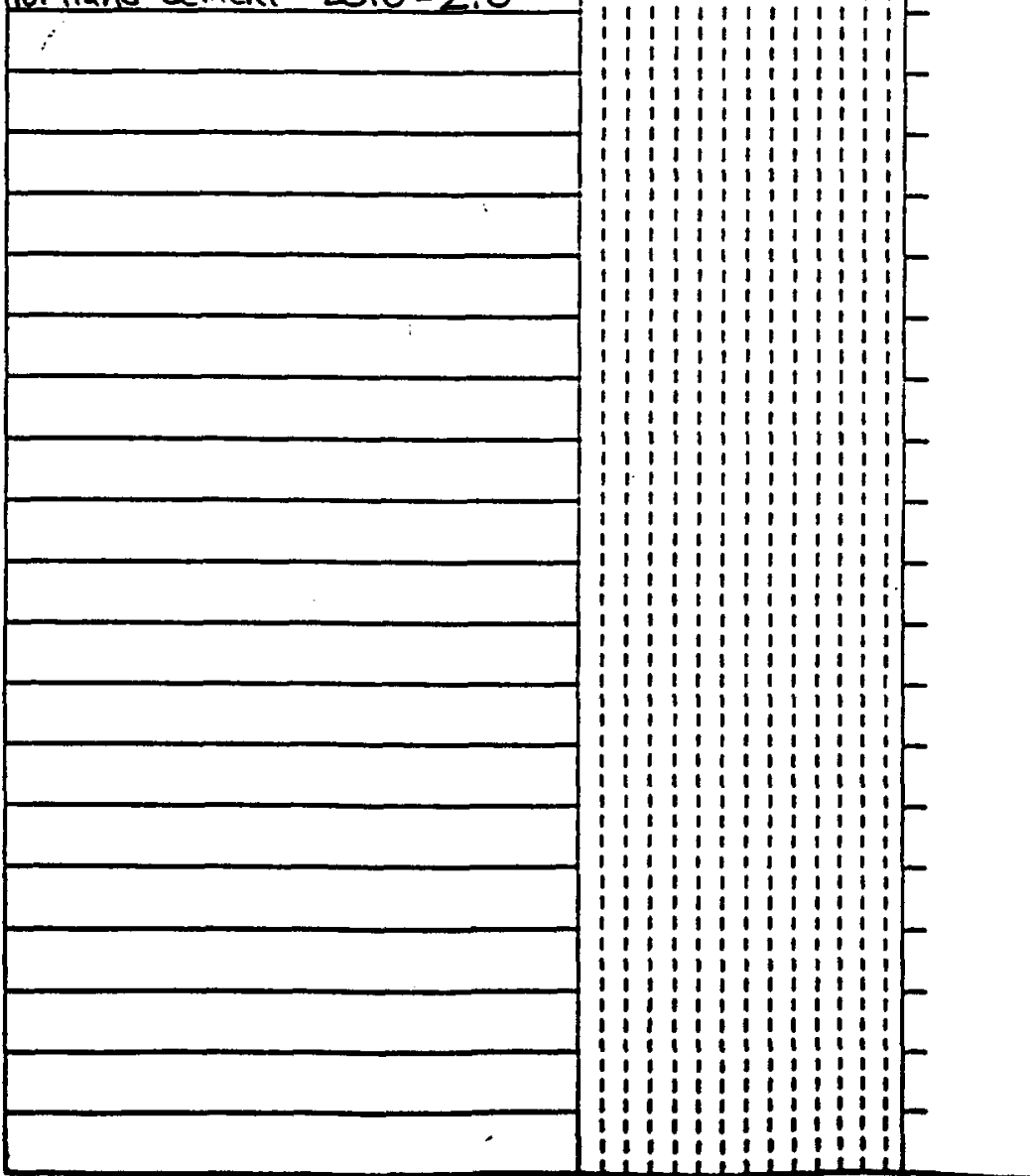

\begin{tabular}{l} 
TDQ230.1 ft \\
\begin{aligned} & \hline TATIC WATER LEUEL \\
& \hline O 218.65 on $1 / / 7 / 91 \\
&$\hline \\
& \hline \\
& \hline \\
& \hline \\
& \hline \\
& \hline \\
& \hline \\
& \hline\end{aligned} \\
\hline
\end{tabular}


A 4856

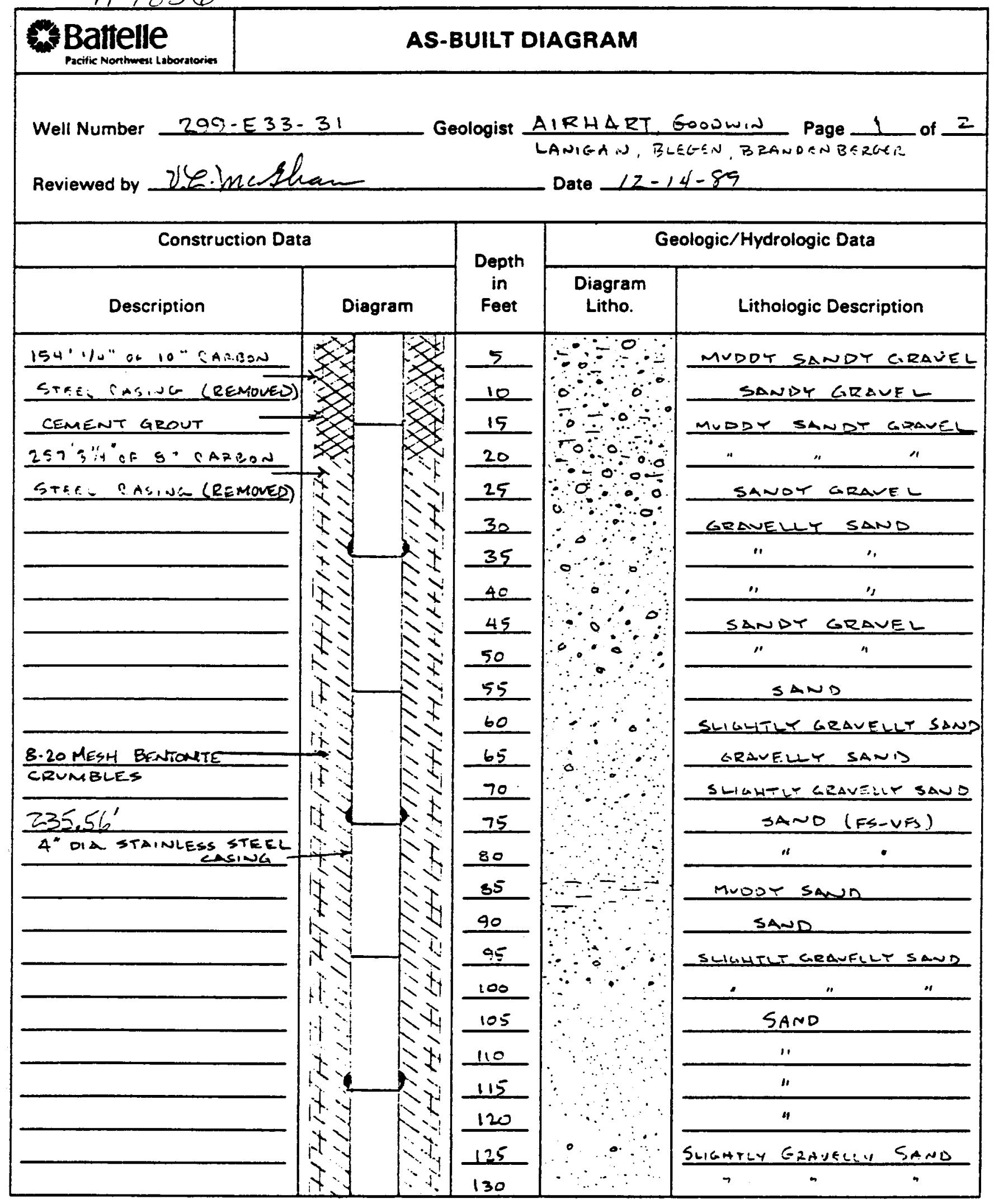

A.1800-186 (3/87) 


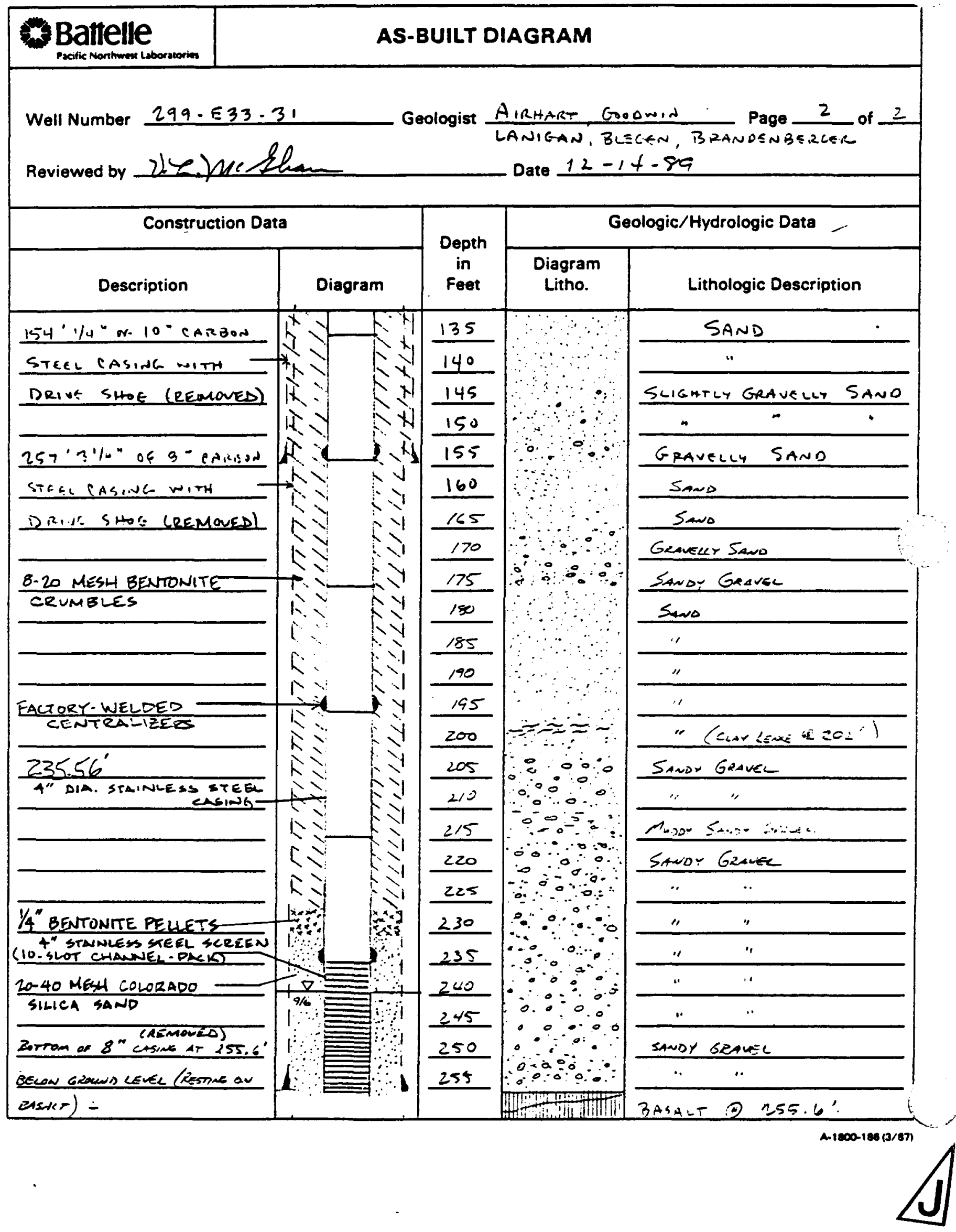


WELL SUMMARY SHEET

Well ID: C4lao

Location: wasz of c-Tank Farm

Prepared By: Charlene Jmartine?

Signature: chosens thartine CONSTRUCTIONDATA

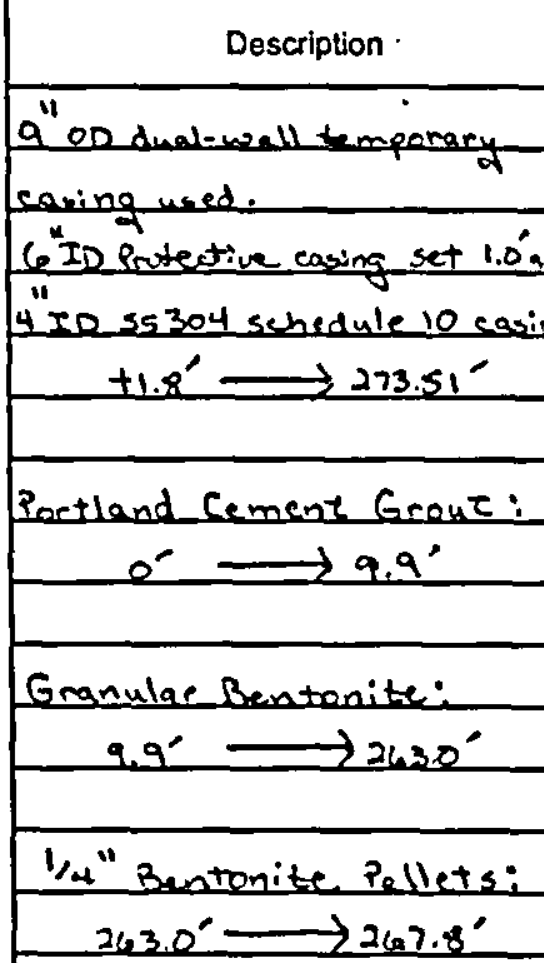

क

All temporsary casing removed from ground:

All depths in feet below greound surface.

P

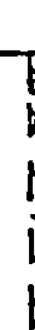

ivi

Ci.

R.

i'

i.

in

i.

hi.

fiy

E.

ris

i.

i.

iv

i.

ki

iv

i.y

(1)

iv
Start Date: colos 103 Finish Date: $08 / 12103$

Page 1 of 2

Well Name: $299-E 27-23$

Project: CYO3 RCRA drilling

Reviewed By: L.D.Walker

Signature: ito

Date: $9 / 5 / 03$

Date:oslugles

\begin{tabular}{|c|c|c|}
\hline \multirow{2}{*}{$\begin{array}{l}\text { Depth ir } \\
\text { Feet }\end{array}$} & \multicolumn{2}{|c|}{ GEOLOGICIHYDROLOGIC DATA } \\
\hline & $\begin{array}{c}\text { Graphic } \\
\text { Log }\end{array}$ & Lithologic Description \\
\hline
\end{tabular}

Diagram

$\square$

0100

$0^{\prime}-15^{\prime}$ Bactfiul (Crusbed GRaucL)

$1.5^{\prime}=10^{\circ} \operatorname{san} 0(5)$

$10^{\circ}-12^{\prime}$ gravelly $\operatorname{sen} \theta(q 5)$

$12^{\prime}-15^{\prime}$ sand $y$ GRAUE $L(56)$

$15^{\prime}-20^{\prime}$ gravelly $\operatorname{san} 0(q 5)$

$20^{\prime}-103^{\prime} \operatorname{sanOS}(5)$

i.

iv

Ris

i'

i.

Niy

IV) 
WELL SUMMARY SHEET

Well ID: C.4190

Location: wesz of $c$-Tank Faem Prepared By: Charlene Martine Signature: charene martime CONSTRUCTIOFDATA

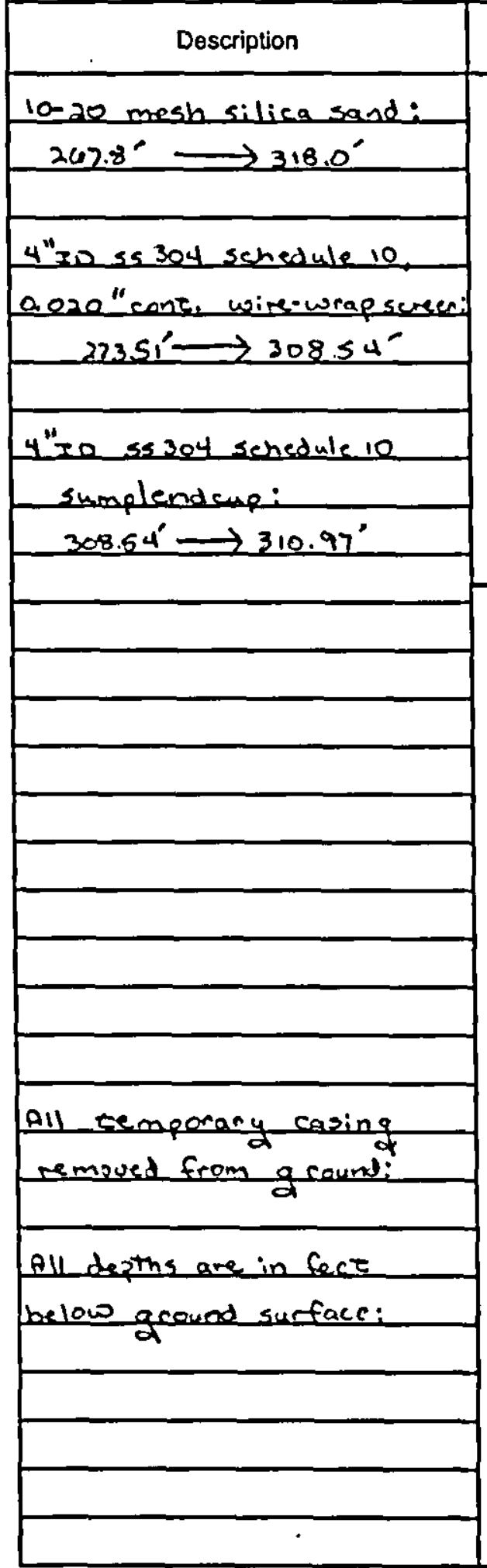

Start Date: os los lo 3 Finish Date: $08 / 12103$

Page 2 of 2 Well Name: $299-627-23$

Project: cyo3 BCRAdrilling

Reviewed By: L.O. WalKer Signature: $2 A$ ACL.

Date: $9 / 5 / 03$

Dato:os/iglos

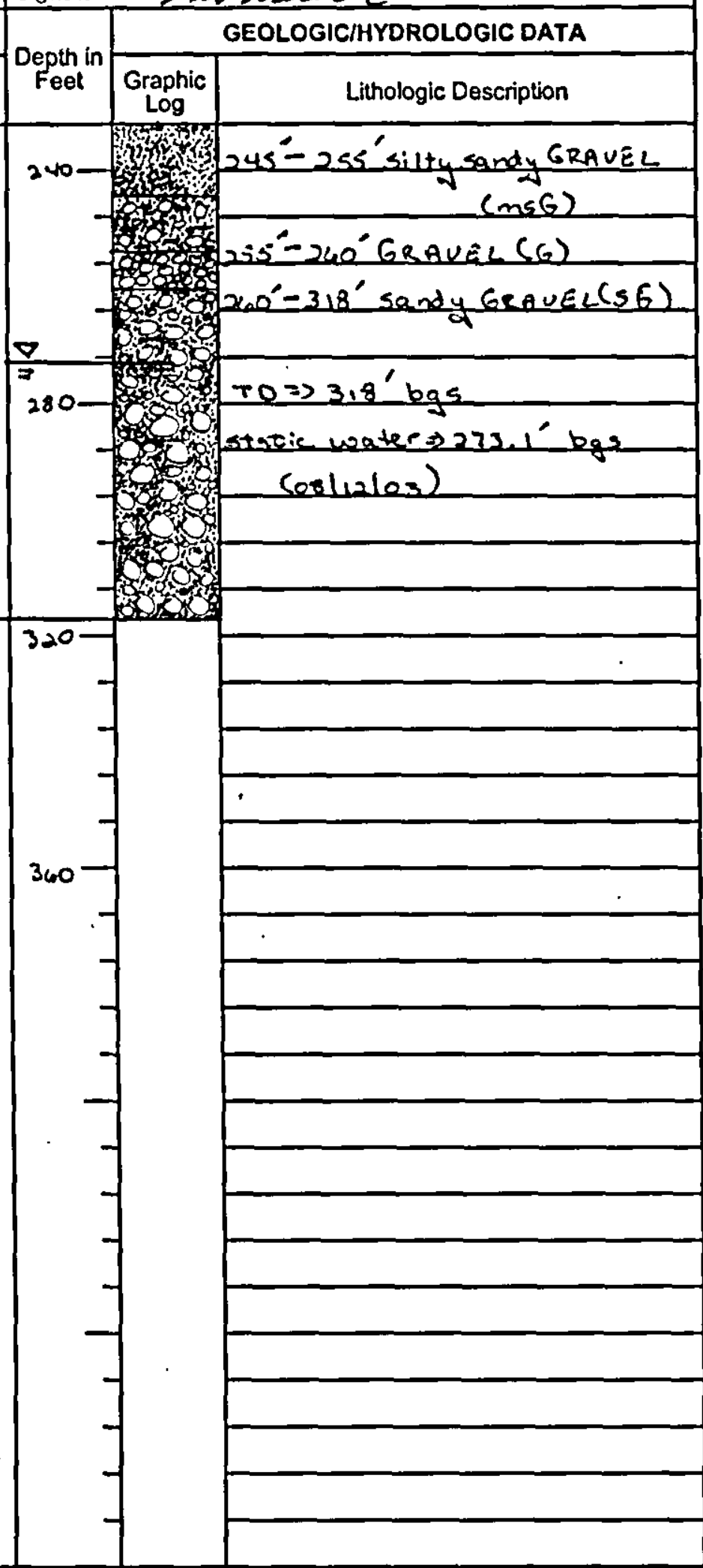




\section{WELL CONSTRUCTION SUMMARY REPORT}

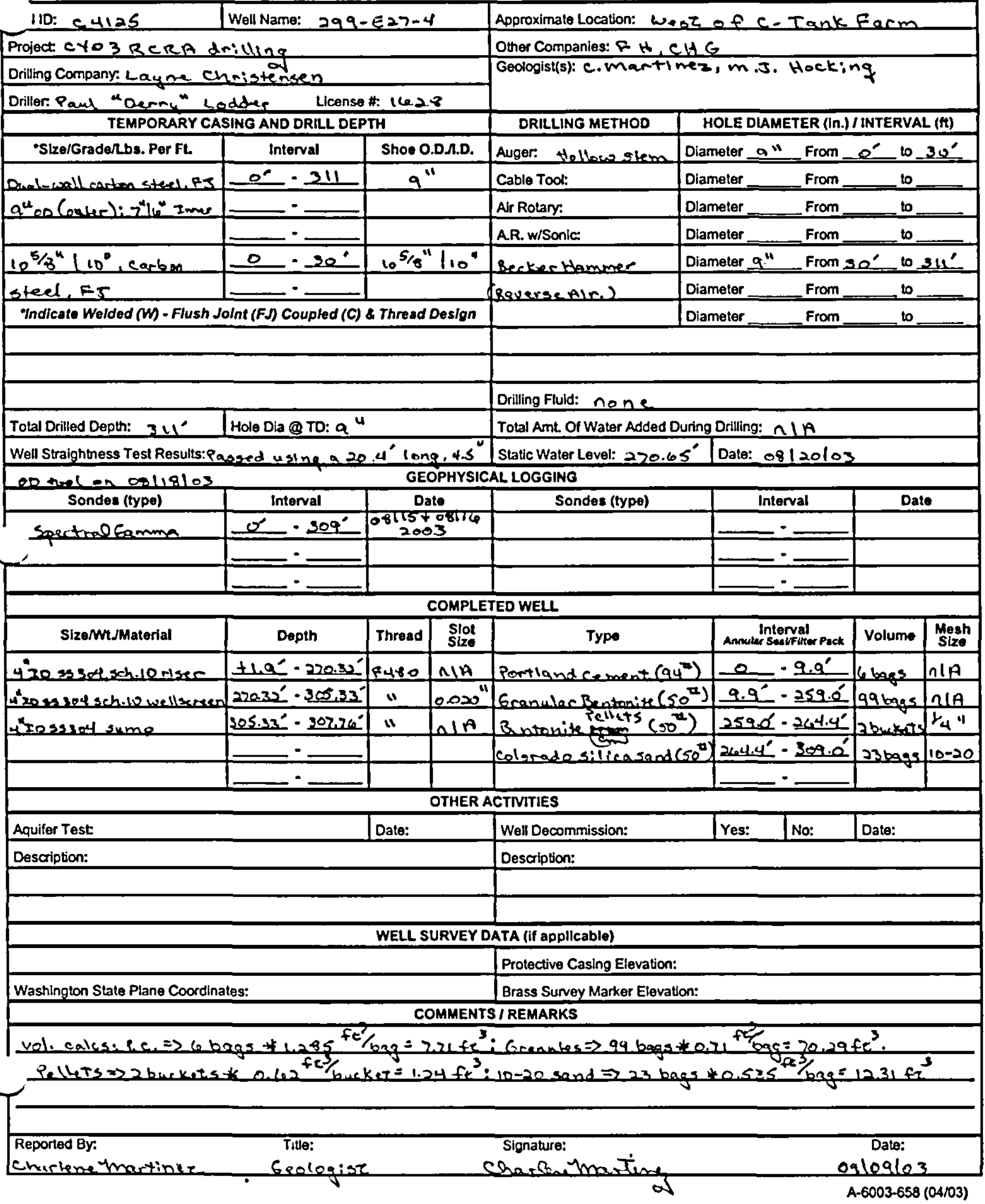




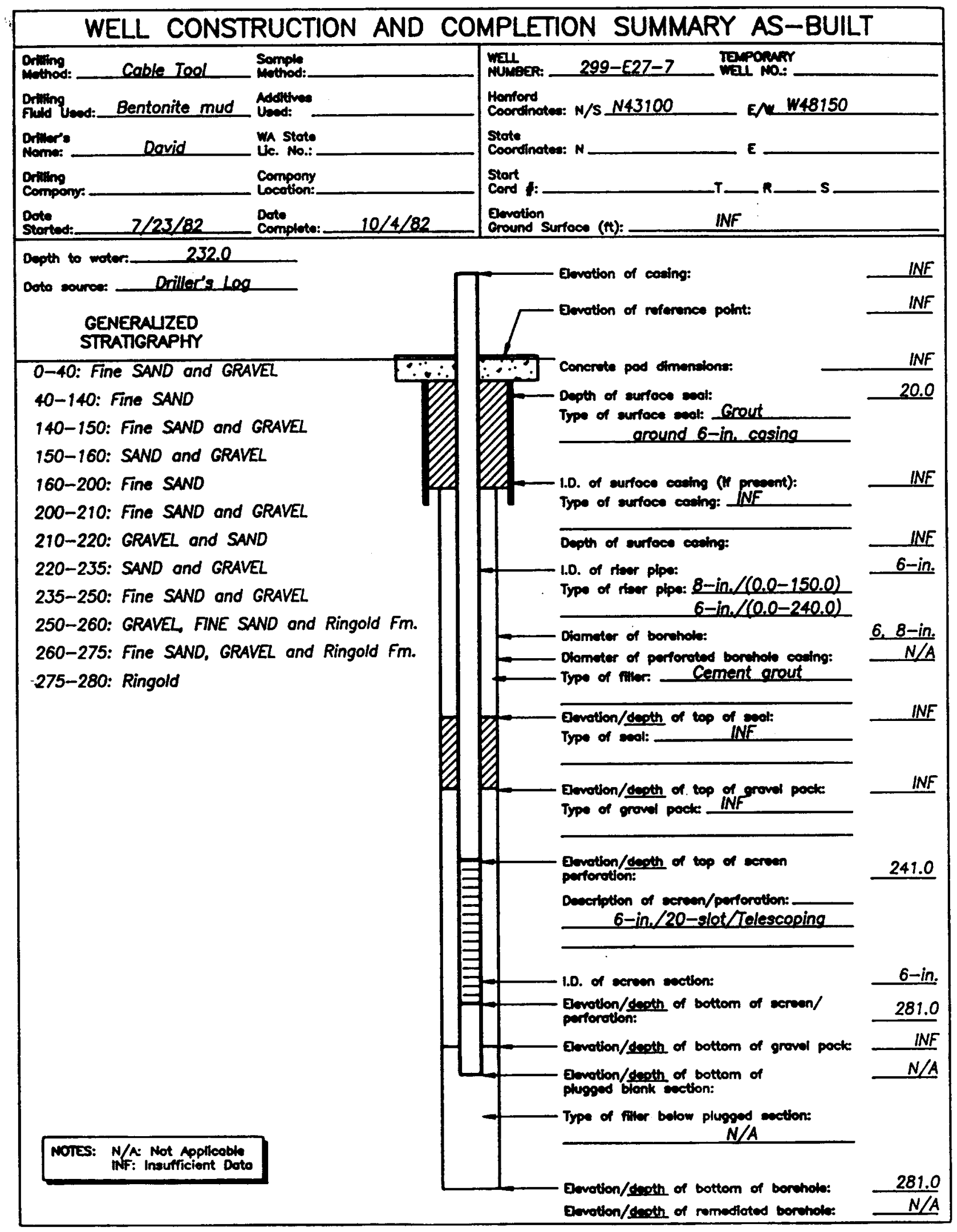

$8031752 \backslash 14120$ 
WELL SUMMARY SHEET

Well ID: 54127

Location: South of $E R$ - vaule

\begin{tabular}{|l|l|} 
Prepared By: Charlene Martiner & Dato:oplorlos \\
\hline
\end{tabular} Signature: choren, Thantine CONSTRUCTION DAKA

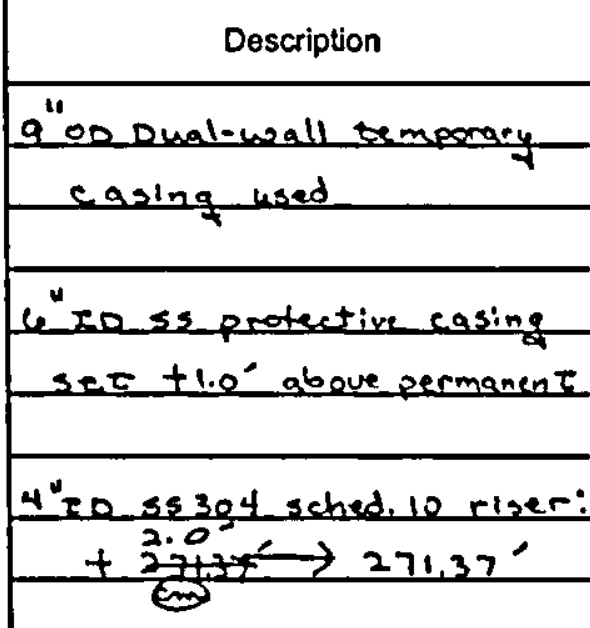

Portland Cemant Geout: $0^{\prime} \rightarrow 10,1^{\prime}$

Granular Bentonite: $10.1^{\prime} \longrightarrow 26.4^{\prime}$

Va" Bentonite Pellets: $260.4^{\prime} \longrightarrow 265.5^{\circ}$

All temporary sasing remoued from ground:

All dspths arsin feer belous ground surface.
Diagram

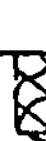

87

$5 .-$

$+2$

is

兴:

心

5:

ri:

ㄷ:

(:)

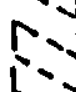

r:

ㄴ.

空

in

si

5

(i)

ㄴ.

(5)

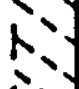

今.

n.

E.

in

is

sis

inis

inis

wis

$[-7$

E-

$k=1$

$5-\frac{1}{1}$

Ri-

$-1$

E-y

$-1$

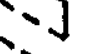

$2 \geq$

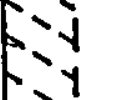

Start Date: or 2103

Finish Date: orlaslo3

Page 1 of 2

Well Name: 299-E 27-21

Project: $C Y 03$ RCRA drilline

\begin{tabular}{ll|l} 
Reviewed By: L.D. WalKer & Date: 8/11/03
\end{tabular}

Signature:

\begin{tabular}{|c|c|c|}
\hline \multirow{2}{*}{$\begin{array}{l}\text { Depth in } \\
\text { Feet }\end{array}$} & \multicolumn{2}{|c|}{ GEOLOGIC/HYDROLOGIC DATA } \\
\hline & $\underset{\text { Log }}{\text { Graphic }}$ & Lithologic Description \\
\hline
\end{tabular}

0

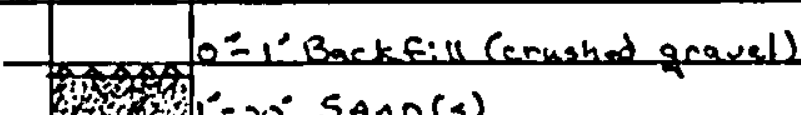

$\because-20^{\circ} \operatorname{san}(s)$

$20^{\prime}-25^{\prime}$ qravelly $\sin D(q 5)$

$25^{\circ}-40^{\circ} \operatorname{san} 0(5)$

40

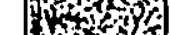

(1) $40-65^{\prime}$ gravelly $\operatorname{send}(05)$

-1
-1
-1

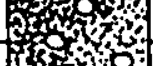

toxis

Hix

- Pof $65^{\circ}-1160^{\circ} \operatorname{san} 0(5)$

120

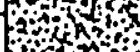

int.

(a)

ins

$10 \%$

a 3 in

3xe?

s

40

is

160

Th

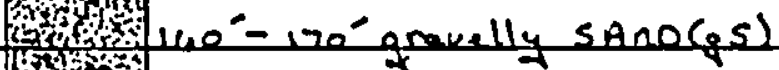

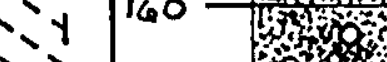

$170^{\circ}-185^{\circ} \operatorname{san} 0(5)$

$185^{\prime}-200^{\circ}$ sHty sandy GRAVEL

s.s.

trition

ofing

isosicis

200

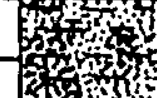

200 - $225^{\prime} s i 1+y \operatorname{sand}(\mathrm{m} 5)$ (ms6)

$225^{\prime}-235^{\prime}$ silty sandy GRnves
(msc)
A-6003-643(03/03) 
Start Date: ol/2103 Finish Date: 07125103

Well 10: 14127

Location: Sowth of $C R$-Uaule

Prepared By: sendene Martiner

Signature: conorlons Thantin CONSTRUCTION DATA

\begin{tabular}{c} 
Description \\
\hline $10-20$ mesh sillca sand \\
\hline $2.5 .5^{\prime} \longrightarrow 314.0^{\circ}$
\end{tabular}

Ss $304\left(4^{4}\right.$ ID) schedule 10 $0.020-i n$ cont. wire-wrap wellscrean:

$221.37^{\circ} \longrightarrow 306.43^{\prime}$

4 "20 35304 schedule 10

sumplendcap:

$306.43^{\prime} \longrightarrow 308.83^{\prime}$

$4-8$ mesh silica sand: $314.0^{\circ} \longrightarrow 318.0^{\circ}$

All temporacy casing remoued from oround:

All depths are in feet below ground surface.
Well Name: $299-E 27-21$

Project $C Y 03$ ReRn drilling

Date:oslorlo3 Reviewed By: L. D. Walker signature: $20 \mathrm{HaCh}$

\begin{tabular}{|c|c|c|}
\hline \multirow{2}{*}{$\begin{array}{l}\text { Depth in } \\
\text { Feet }\end{array}$} & \multicolumn{2}{|c|}{ GEOLOGIC/HYDROLOGIC DATA } \\
\hline & $\begin{array}{c}\text { Graphic } \\
\text { Log }\end{array}$ & Lithologic Description \\
\hline
\end{tabular}

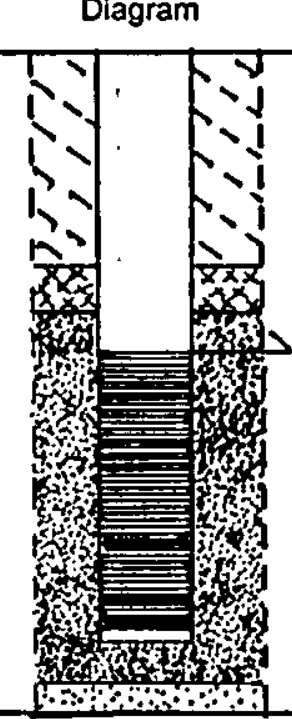

320

$T O=318^{\circ} \mathrm{bgs}$

static water $271.38^{\prime} \mathrm{bgs}$ (or 25103$)$ 
Well Number $299-\varepsilon 27-10$ Reviewed by thipathene

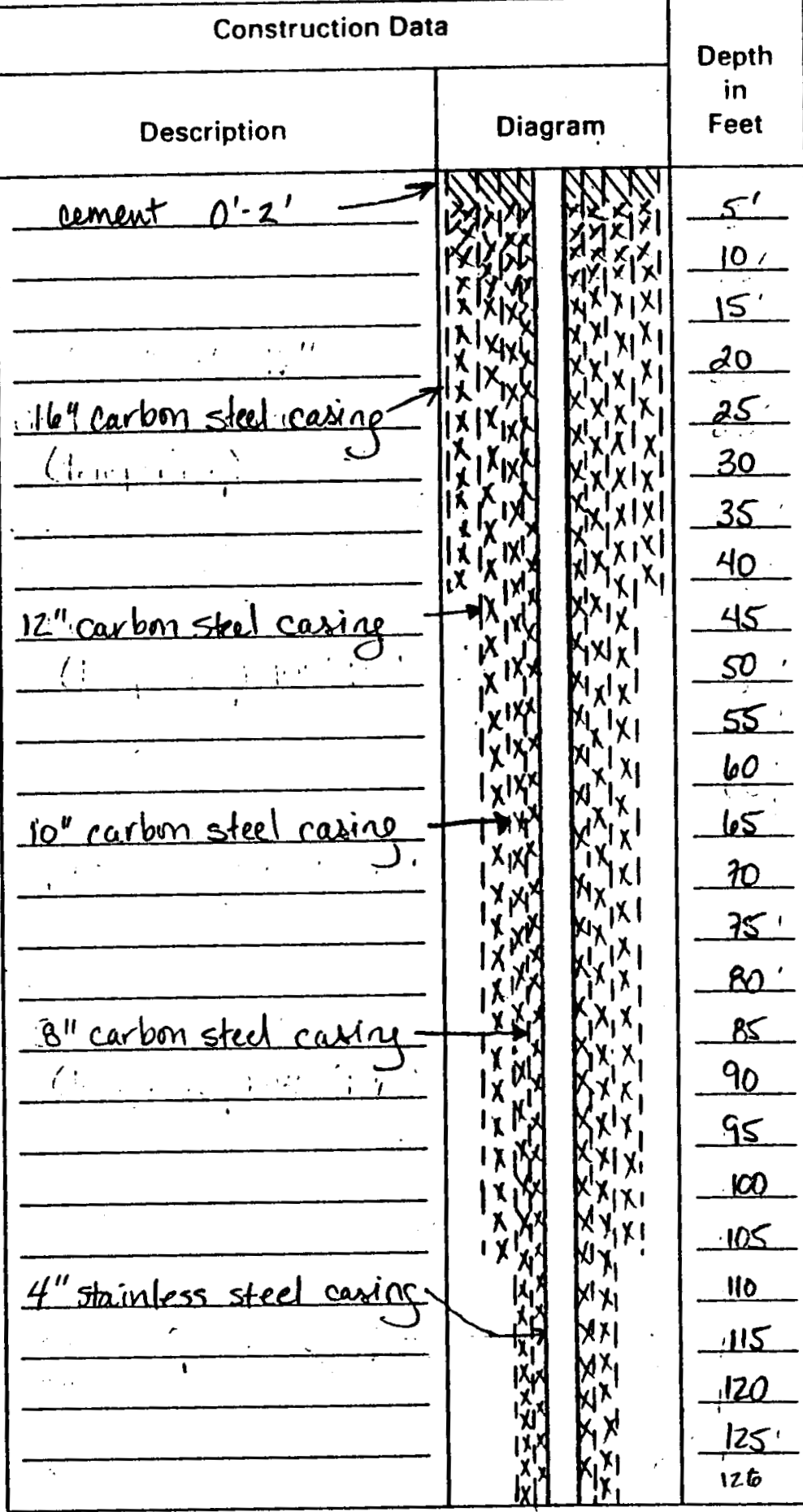

Geologist XROster /P. White Page 1 of 2 R. Hagen, M.A. Chauress, S. Dudziale, R.Premzic S Airhout, S.Goodurin Date $22-21-87$
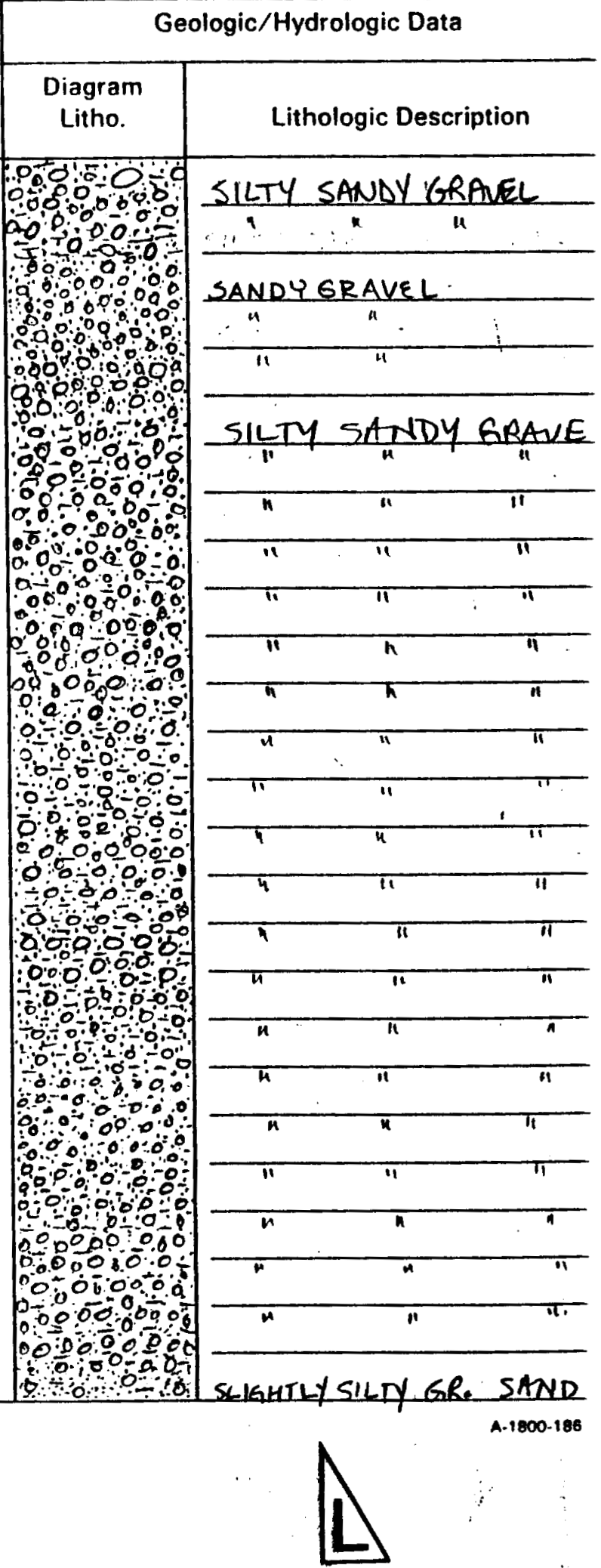
Well Number $299-E 27-10$ Reviewed by yinialha Construction Data

bentonite crumbles $200^{\circ}-2$

$4^{\prime \prime}$ stinless stael casing

centralizers

volelau fellets $206^{\circ}-20^{\circ}$ 4" Sninless stons screen

D/W 215.8, 8/5/87 20130 silica sand $240^{\prime}-206^{\circ}$

10'1l" of 8" stainless steel telescoping screen
Geologist KR OTber P White Page 2 of 2 R. Hagen S. Dudziak, MA.Chamners, R. Fremic, S. Aiphart, S. Ezoduiniz-21-87

Geologic/Hydrologic Data

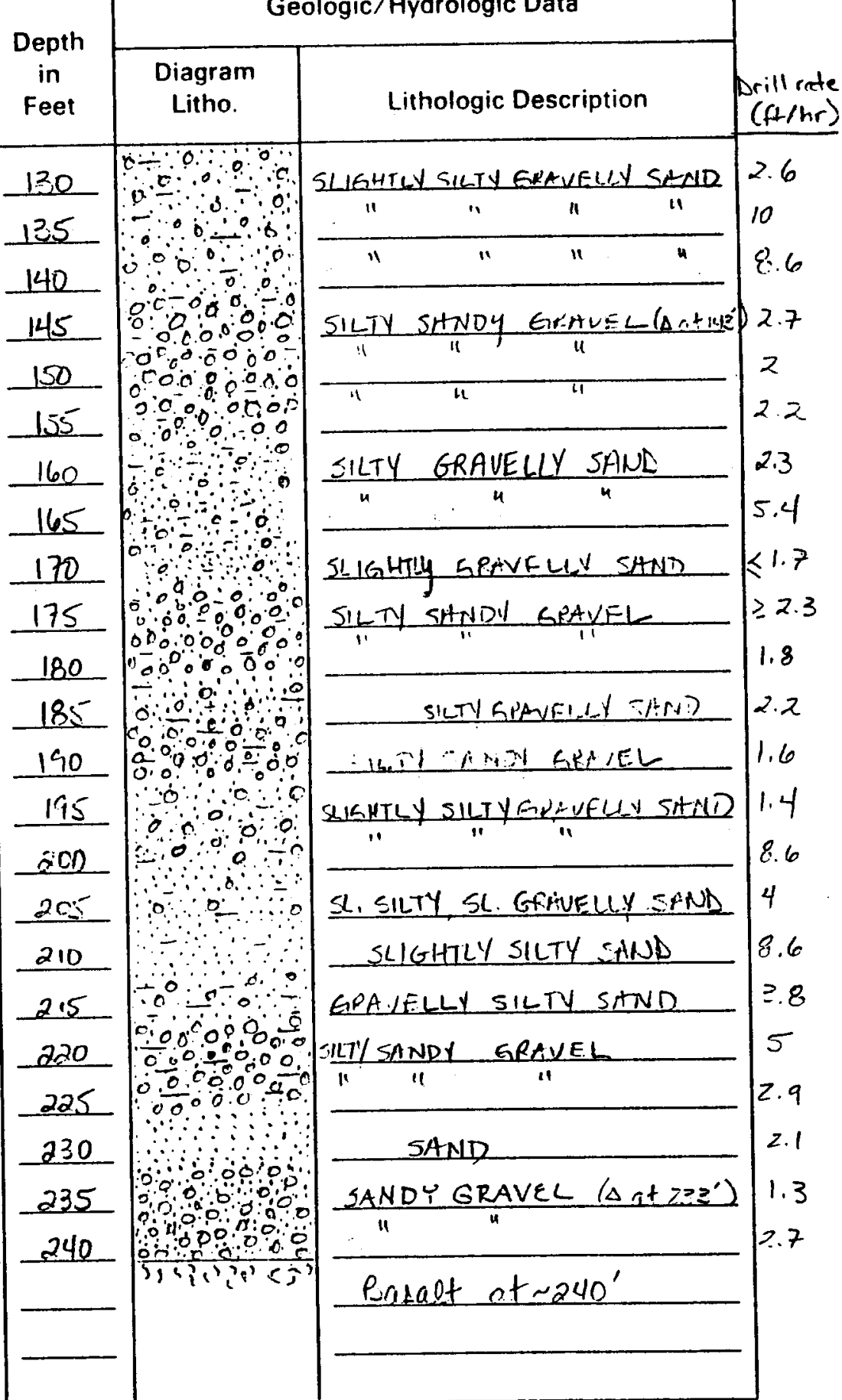

A. $1800.186(3 / 87)$

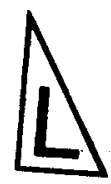




\section{Distribution}

No. of

Copies

6 CH2M HILL Plateau Remediation Company

G. S. Thomas (5)

C. D. Weittreich
R3-50

H8-15
No. of

Copies
3 Pacific Northwest National Laboratory

S. N. Schlahta

K6-83

M. D. Sweeney (2)

K6-75 




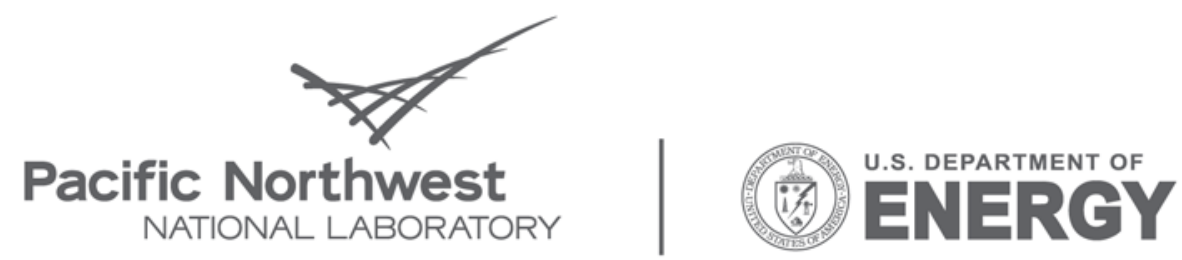

Proudly Operated by Battelle Since 1965

902 Battelle Boulevard

P.O. Box 999

Richland, WA 99352

1-888-375-PNNL (7665)

www.pnl.gov 